\title{
Türk Milliyetçiliğinde Antisemitizm: Hüseyin Nihal Atsız Yazıları Üzerine Bir İnceleme
}

\author{
Yusuf Ziya BÖLÜKBAŞI*
}

Türk Milliyetçiliğinde Antisemitizm: Hüseyin Nihal Atsız Yazıları Üzerine Bir İnceleme

\section{Özet}

Bu çalışmada, Türk milliyetçiliğinin en önemli kalemlerinden biri olan Hüseyin Nihal Atsı'ın yazılarındaki antisemitist öğeler incelenmek istenmektedir. Atsı' In yazılarında işlediği antisemitist öğelerdeki temel saik nedir? sorusu etrafında mevcut çalışma şekillenmektedir. Bu minvalde mevcut çalışmanın metodolojik çerçevesini eleştirel söylem analizi tekniği oluşturmakta, Atsız'ın eserlerinde yer verdiği, Yahudi, Mason, Sabetayist ve İsrail kavramlarını işleyiş biçimi tema analizi vasıtasıyla irdelenmektedir. Atsız'ın yazılarındaki antisemtizmin ideolojikırki bir nitelik taşıdığı görülmektedir. Yahudilik ve Yahudiliğe ilişkin kimlik ve ideolojiler -Mason, Sabetayist, Siyonizm ve Komünizm- düşman ve öteki olarak kodlanmaktadır. Ancak Atsız, milli ülkü çerçevesinde Yahudileri takdir etmeyi ihmal etmemektedir. İsrail örneği üzerinden Turancılığı meşrulaştırmasına rağmen Atsız, İsrail'i büyük bir tehlike olarak görmektedir.

Anahtar Kelimeler: Atsı, Antisemitizm, Yahudi.
Antisemitism in Turkish Nationalism: An Investigation on Hüseyin Nihal Atsız Writings

Abstract

In this study, it is aimed to examine the anti-Semitic elements in the writings of Hüseyin Nihal Atsız, one of the most important items of Turkish nationalism. The current work around the question, what is the main motive in the anti-Semitic elements of Atsı's writings? is shaped. In this context, the methodological framework of the present study constitutes a critical discourse analysis technique, and the way in which Atsı's works are used to examine the concepts of Jewish, Mason, Sabetayist and Israel is examined through theme analysis. Antisemtism in Atsı's writings seems to have an ideological-racial character. The identity and ideologies of Judaism and Judaism - Mason, Sabetayist, Zionism and Communism - are codified as enemies and others. However, Atsız does not neglect to appreciate the Jews within the framework of the idea of national ideal. Atsız sees Israel as a great danger, although he legitimizes Turanianism from the Israeli example.

Key Words: Atsız, Antisemitism, Jew.

\section{Giriş}

Antisemitizm, tarihsel bir fenomen olarak, bazı bilim adamlarına göre tarihin çok eski devirlerine -Yahudilerin ilk Babil Sürgününe- kadar geri götürülse de, modern bir kavram olarak Avrupa'da ortaya çıkmıştır. Bu kavramın ortaya çıkışında en etkili olgu milliyetçiliğin doğuşuydu. Fransız İhtilali ile birlikte ortaya çıkan milliyetçilik, çok kısa bir sürede önce Avrupa'ya, daha sonra da dünya

*Yusuf Ziya BÖLÜKBAŞı, Dr.Öğr.Üyesi., Bilecik Şeyh Edebali üniversitesi, Uluslararası ilişskiler Bölümü,yusuf.bolukbasi@bilecik.edu.tr, ORCID ID orcid.org / 0000-0003-4723-5977 
Yusuf Ziya BÖLÜKBAŞI

savaşları vasıtasıyla bütün yer küreye yayılmıştır. Bu süreçte milliyetçiliğin Avrupa'da büründüğü biçim, diğer toplumlarda aşağı yukarı benzer bir etki göstermiş, genellikle milli kimlik inşalarında öteki olgusuna yönelik saldırgan bir tavrın etkili olmasını beraberinde getirmiştir. Orta ve Doğu Avrupa'da, ulus-devletlerin kuruluşu ve milli kimlik inşası süreçlerinde, öteki olarak Yahudiler konumlandırılmış, bu durum II. Cihan Harbinin sonuna kadar devam etmiş̧i.

Osmanlı İmparatorluğu'nda milliyetçilik, ilk etapta Balkanlarda bulunan Hristiyan etnik gruplar arasında yayılmış, daha sonra Müslüman gruplara sirayet etmiş ve en son Türkler tarafından kabul görmüş bir ideolojidir. Aynı zamanda Osmanlı İmparatorluğu, Balkanlar, Anadolu ve Ortadoğu coğrafyalarında yaşayan geniş bir Yahudi nüfusuna da sahipti. Her ne kadar diğer gruplar kadar büyük ve bir bölgede yoğunlaşmamış olsalar da, Yahudiler, Osmanlı millet sistemindeki gruplardan biri olarak kabul edilmekteydiler. İmparatorluğun yıkılması ve ardından Türkiye Cumhuriyeti'nin kurulmasından sonra da Yahudiler İstanbul, İzmir, Bursa gibi büyük şehirler ve Trakya bölgesinde yaşamaya devam ettiler. İşte bu süreçte, Cumhuriyet'in kuruluş evresinden sonra etkili olan ve kendi içinde yol ayrımına giden Türk milliyetçiliğinin Yahudilere yaklaşımı ya da Türk milliyetçiliğinde antisemitist bir nüvenin bulunup bulunmadığı sorusu bu çalışmanın kaleme alınmasına neden olmuştur. Bu minvalde, öncelikle Osmanlı İmparatorluğu ve erken Cumhuriyet dönemlerinde Yahudilerle ilgili yaşanan hadiselere kısaca bakılacaktır. Bundan sonra mevcut çalışmanın metodu olan söylem analizi ve kuramsal yaklaşım irdelenecektir. Daha sonra antisemitizm kavramı ve Türk milliyetçiliği içindeki önemli bir yol ayrımını temsil eden Türkçü-Turancı milliyetçiliğin mütefekkiri Hüseyin Nihal Atsız'ın Türkçülük tasavvuruna yer verilecektir. Bundan sonra Atsız'ın Yahudilerle ilgili söylemleri incelenecek ve sonuç bölümünde çalışmada cevabı aranan soru/sorular cevaplanacaktır.

\section{Tarihsel Arkaplan}

Türk milliyetçiliği, 19. Yüzyılın sonlarında girift ve çeşitli süreçlerin etkisiyle, Osmanlı İmparatorluğunda meydana gelen siyasi, ekonomik ve sosyolojik dönüşümlerin neticesinde ortaya çıkmıştır. Kösoğlu'nun (2009, s. 209) da belirttiği üzere, Türk milliyetçiliği, asker ve sivil bürokrasinin öncülüğünde emperyal güçler karşısında yıkılmakta olan imparatorluğu kurtarma saikiyle vücut bulmuştur. Ancak her açıdan tükenmiş bir imparatorluğu ayakta tutamayan Türk milliyetçiliği, elde kalan ve daha sonra bir kısmı kurtarılan topraklar ve insanlardan yeni bir devlet ve millet inşa etti. Böylece yeni devlet Türk milliyetçiliği -ya da bunun farklı bir formu olan Kemalist milliyetçilik- üzerine kurgulandı. Bu süreçte doğal olarak, Türk milliyetçiliği ve onun tarafından inşa edilen Türk kimliği, bütün milliyetçilik tasavvurlarında olduğu gibi, bir "öteki" kimliğe karşı inşa edilmiştir. Cumhuriyet Türkiye'si, büyük oranda homojenize edilmiş bir nüfus ve coğrafyaya sahip olduğu için bu öteki kodlaması içeriye karşı gerçekleştirilmiştir. Aydın’a (2009, s. 355) göre bu öteki, ulusal kimliğin ve bilincin İslamiyet ve kozmopolit Osmanlı unsurlarından temizlenmesini içermektedir. Dündar (2009, s. 893) ise, içeride inşa edilen Türk kimliği için tehdit oluşturan azılıkların öteki olarak konumlandııılığını ifade etmektedir. Çünkü bu azınlıklar Osmanlı İmparatorluğunun yıkılmasının müsebbibidirler, dış devletler tarafından iç işlerimize yapılan müdahalelerin sorumlularıdırlar, dola- 
yısıyla devletin bekasını tehdit eden başlıca mihraklardır. Böylece Türk milliyetçiliği, tek bir öteki yerine, birden çok "iç" öteki karşına kendisini konumlandırmakta ve retoriğini bu çerçevede şekillendirmektedir. Gerçi Türk milliyetçiğinin ortaya çıkısında yok olma korkusu, Batı dünyasının çifte standardı, Hristiyan azınlıkların yıkıcı faaliyetleri ve Müslümanlara yönelik katliamların oluşturduğu duygu iklimi neticesinde beliren tepkisellik etkili olmuştu (Akçam, 2009, s. 57-62) ve bu tepkisellik etnik ve dinsel azınlıklara karşıydı. Osmanlı İmparatorluğunun çöküşü ve daha sonra kurulan ulusdevletle birlikte nüfus içinde küçük bir azınlığı oluşturan gayrimüslimler, Türk milliyetçiliği açısından tehdit olarak görülmeye devam edilmiştir. Bu gayrimüslim azınlıklardan birisi de Yahudilerdir.

Türklerle Yahudiler arasındaki ilişkiler çok eski tarihlere kadar geri götürülebilse de, Osmanlı İmparatorluğu dönemi bu ilişkilerin en yakın olduğu periyottu. Yahudiler, Roma İmparatorluğunun Kudüs'ü ele geçirmesinden sonra dünyanın dört bir tarafında dağılmış ve gittikleri yerlerde büyük zorluklarla karşılaşmışlardı. Osmanlı İmparatorluğundaki Yahudilerin durumu her daim Avrupa'da yaşayanlardan daha iyi görünmekteydi. Bunun temel sebebi Osmanlı yönetim biçimini oluşturan Millet Sistemiydi. Millet sistemi tamamen dini farklılıklara göre dizayn edilmişti. Her dini grup kendi içinde özerkliğe sahipti. Hâkim millet ise Müslümanlardı. Osmanlı bu şekilde hiçbir milletin -ki beş tane millet bulunmaktaydı: Müslüman, Ermeni, Yahudi, Katolik, Ortodoks- iç işlerine müdahale etmemekte, dini referanslarla yönetimi sağlamaktaydı. Osmanlı içindeki en büyük Yahudi grubunu, 15. ve 16. Yüzyıllarda İspanya ve Portekiz'den gelenler oluşturmaktaydı. Bunlar Ladino dili konuşan Yahudilerdi. Bunların dışında Osmanlı'nın içinde yaşayan diğer Yahudiler bulundukları bölgeye ait dilleri konuşmaktaydı. Osmanlı'daki Yahudilerin durumu, Avrupa'daki soydaşlarıyla mukayese edildiğinde gayet iyi durumdaydı, başlarına hiçbir zaman 17. yüzyılın sonunda Polonya'da yaşanan Khmelnitsky katliamı gibi bir olay gelmedi (Lewis, 2018, s. 66-67). Osmanlı İmparatorluğunda Yahudilerle alakalı en büyük sorun Sabetayizm hususunda yaşandı. Ortaçağ Kabbalist metinlerinden oluşan Zohar'da Sabetay Sevi, İsrail halkının uzun süredir beklediği ve onları vaadedilmiş topraklara götürecek olan Mesih'in geleceğine ilişkin kehanetini 1648 ylında söyledi. Sevi etrafında toplanan müritlerine Mesih olduğunu ve bütün Yahudileri kutsal topraklarına götüreceği vaadinde bulundu. 1666 yılını Mesih yılı olarak ilan etti. Ancak Sabetay Sevi'nin bu iddiaları Osmanlı sarayında rahatsızlık yarattı. Padişah IV. Mehmet Sevi'yi yakalatarak huzuruna getirdi. Kendisini Mesih olarak ilan eden Sevi'den bir mucize göstermesini istedi. Doğal olarak bu mucizeye sahip olmayan Sevi, Sultandan af dileyerek Müslüman oldu. Her ne kadar bu durum Yahudiler açısından bir suküt-u hayal olsa da, onun hala Mesih olduğuna inan kişilerde bulunuyordu. Bu inanca sahip olanlara "Sabetayist" ya da Türkiye'deki ifadesiyle "dönme" denilmektedir. Ayrıca "Selanikli" diye anılan Sabetayistlere yönelik çeşitli suçlar işlediklerine ilişkin ithamlarda da bulunulmaktadır. Özellikle İslamcılar için Sabetayistler bütün komplo teorilerinin merkezinde bulunmaktadır. Hatta modern Türkiye'nin kurucusu Mustafa Kemal Atatürk'ün bile Sabetayist olduğu ileri sürülmektedir. Ancak Atatürk'ün Sabetayist olmadığı kesin bir olgudur. Komplo teorilerinin merkezinde yer almalarının sebebi ise II. Meşrutiyet'in ilanında ve Cumhuriyet'in kuruluşunda oynadıkları roldür. Bu durum, yani sırasıyla meşruti monarşi ve Cumhuriyet rejimlerini desteklemeleri, laiklik taraftarı olan Sabetayistler için gayet rasyonel bir tercih olduğu söylenebilir (Edel, 2008, s. 23-32). 
Osmanlı İmparatorluğunda Sabetayizmin dışında Yahudiler ve Türk yönetiminin karşı karşıya geldiği en önemli mesele Siyonizmin doğuşu ve Yahudilerin Filistin topraklarında yurt kurmak istemeleriydi. Siyonizm, ilk etapta, ortak bir tarih ve kültür temelinde birleşen ve amacı Yahudilerin kutsal vatanı Eretz Yisrael'de bir devlet kurmak olan etno-kültürel Yahudi milliyetçiliğinin adıydı (Gans, 2008, s. 3). Siyonizmin en önemli temsilcisi ise Avusturyalı gazetece Theodor Herzl idi. Herzl, öncelikle Yahudilerin eski yurtlarına dönebilmesi için II. Abdülhamit Han'ın ikna edilmesi gerektiğini düşünüyordu. Bu yüzden Polonya asıllı Yahudi asilzade Newlinski vasıtasıyla Sultan’la görüşmek istedi. Bu görüşme gerçekleşmeyince Avrupa'daki zengin Yahudilerden Siyonizme destek istedi. Paris'te Edmond Rotschild ile bir araya geldi. Zenginler Herzl'in fikirlerine temkinli yaklaşınca tekrardan yüzünü Osmanlı'ya çevirdi. Bu süreçte, 29 Ağustos 1897 yllında İsviçre'nin Basel şehrinde I. Siyonist Kongresinin toplanmasını sağladı. Herzl daha sonra İstanbul'a gidecek olan Almanya İmparatoru Kayzer II. Wilhelm ile görüştü ve ondan hem destek, hem de Sultan’ı ikna etmesini istedi. Ancak bunda muvaffak olamayınca tekrar Sultan'la görüşmek istedi. 1901 yılında bu isteği gerçekleşen Herzl, dünya üzerinde Yahudilerin tek dostunun Osmanlı İmparatorluğu olduğunu söyledi. Sultan'ı ikna edebilmek için o dönemde Osmanlı'nın en büyük sorunu olan ekonomik sorunlar ve dış borçlar meselesini ön plana sürdü. Hicaz Demiryolu hattı için iki yüz lira bağışlayan, ancak Müslüman olmadığı için bağışı geri çevrilen Herzl, Avrupa'da Osmanlı borçlarını yapılandırmak ve bu borç sorununu çözmek için çeşitli temaslar ve görüşmelerde bulundu. 1902 ylında İstanbul'a çağrılan Herzl, Sultan'la yüz yüze görüşememesine rağmen, Sultan'ın Filistin'de Yahudilere özerk bir devlet verilmeyeceğini belirtmesinden sonra Avrupa'ya döndü. 1903 yllında Avusturya'da vefat etti (Herzl, 2017, s. 20-44).

Osmanlı İmparatorluğunun son dönemlerinde Siyonistlerin ziyaretleri, Türk siyasetindeki etkileri ve hedefleri Yahudiler ve Türklerin arasındaki ilişkilerin bozulmasına neden oldu. Theodor Herzl'ın İstanbul'a gelip bir süre yaşamasının dışında, ileride İsrail Cumhurbaşkanlığı yapacak olan David Ben Gurion, onun halefi Moshe Sharett ve Sabetayist kökenli Ben Zvi Osmanlı vatandaşlığına geçtiler. Doğal olarak Siyonistlerin Osmanlı́ya olan ilgisinin temelinde Filistin toprakları bulunuyordu (Edel, 2008, s. 32-33). Bunun karşısında Osmanlı İmparatorluğu Yahudilere toprak satışını yasaklayarak Siyonist göçünü azaltmaya çalıştı. Ancak Siyonistler hedeflerinin ilk adımını I. Dünya Savaşıyla birlikte attılar. Siyonistler kısa bir süre sonra kendileri için dönemin en büyük küresel gücünden destek buldular. Bu ülke Birleşik Krallık idi. İngiltere Dışişleri Bakanı Arthur Balfour, 2 Kasım 1917 'de, İngiliz kabinesinin ve Siyonist çevrenin ileri gelenlerinden Lord Rotschild'e bir mektup yazarak, Siyonist hedeflere destek olacağını belirtmişti. Balfour Deklarasyonu olarak bilinen bu metin, Siyonizm'e yönelik en büyük destek olarak telakki edilebilir. Balfour'un mektubu şöyleydi: “Krallık hükümeti Filistin'de Yahudi halkı için bir milli yurt kurulmasını uygun karşılamaktadır ve bu hedefin gerçekleştirilmesini kolaylaştırmak için elinden geleni yapacaktır..." (Cleveland, 2008, s. 271).

Birinci Cihan Harbi sonrasında yıkılan Osmanlı İmparatorluğunun yerine Türkiye Cumhuriyeti kuruldu ve bu yeni rejim azınlıklara yaklaşım konusunda Osmanlı'dan daha farklı bir yol izledi. As- 
lında laik-çağdaş bir hukuk sistemine sahip olan yeni devletin milliyetçilik anlayışı, azınlıklara yaklaşımı belirleyen temel ölçüt oldu. Bora, erken Cumhuriyet döneminde yeni devletin azınlıklara bakışını "vücuttan atılan zehir" metaforuyla açıklamaktadır. Bu yaklaşıma göre azınlıklar Türk bünyesini zehirleyen mikroplardır ve bunlardan kurtulmak bedeni yani Türklüğü temizleyecektir. Aslında bu düşünce Balkan Harbi ve Mütareke döneminde yaşanan olayların travmatik etkisiyle açıklanabilir. Yine de erken Cumhuriyet dönemindeki resmi söylemin millet mefhumunda vatandaşlık bağını ön plana çıkarması, etno-merkezci bakışta yumuşamaya neden olduğunu ve Gayrimüslimlerin eğitim ve dil yoluyla Türkleşmesinin mümkün olabileceğini ilişkin bir inanç bulunmaktaydı (Bora, 2009, s. 911).

Cumhuriyet kurulduktan sonra 1927 yllında yapılan nüfus sayımına göre Türkiye'de yaşayan Yahudi sayısı 81.392 kişiydi. Bu rakam Osmanlı İmparatorluğunda 1914 yılında yapılan nüfus sayımındaki Yahudi sayısının -367.400- neredeyse dörtte biri kadardı (Besalel, 2004, s. 99-100). Erken Cumhuriyet döneminde Yahudilerle ilgili yaşanan ya da Yahudilerin sorun yaşadığı üç temel olay bulunmaktaydı: Trakya Olayları, Vatandaş Türkçe Konuş Kampanyası ve Varlık Vergisi. Bunlardan ilki doğrudan Yahudilerle ilgili olmakla birlikte, diğer ikisi bütün azınlıklarla beraber Yahudileri etkileyen gelişmeler olarak telakki edilebilir.

Yahudilerle ilgili Cumhuriyet döneminde doğrudan vuku bulan tek ve ilk olay, "Trakya Olayları" ya da "Trakya Yahudileri Olayı" olarak bilinen, 1934 yılında yaşanmış hadisedir. Olayların temelinde, Almanya'da Nazilerin iktidara gelmesinden sonra bu rejime sempatiyle bakan ve Nazi rejimiyle alakası olmamakla birlikte Türkçü olan bazı yazar ve münevverlerin çeşitli dergilerde neşrettikleri yazıları neticesinde yaşanan şiddet hadiseleri bulunmaktadır. Bunların başında tamamen antisemitist yayınlara yer veren Milli İnkilap Dergisi ve Cevat Rıfat Atilhan gelmektedir. Atilhan, Teşkilat-ı Mahsusa'da Yüzbaşı görevini ifa eden ve Sina cephesinde çalışmış, Almanya'da üst düzey Nazi yöneticileriyle bir araya gelmiş ve bütün ömrünü Yahudi karşıtlığına adamış bir kişidir. Aynı dönemde Hüseyin Nihal Atsız'da çıkartmış olduğu Bozkurt dergisinde Yahudi karşıtı yazılara yer vermişti. Bu yazılara ilaveten ortaya çıkan Yahudilerin zorunlu iskâna tabi tutulacağı dedikodusuyla birlikte pogromlar ilk olarak 24 Haziran tarihinde Çanakkale'de başladı, bunu Edirne, Kırklareli, Silivri, Babaeski, Çorlu, Lüleburgaz ve Lâpseki'de yaşanan şiddet, talan, dayak, yangınlar ve bazı ölümlü vukuatlar izledi. Bunun neticesinde on beş bine yakın Yahudi İstanbul'a göç etti, çok az sayıda Yahudi yurtdışına gitti (Düzgün, 2000, s. 73-76).

Yine Türk olmayan bütün grupları hedef alan ama en çok Yahudileri dönüştürmeyi amaçlayan ve Yahudilerin etkilendiği bir başka olgu "Vatandaş Türkçe Konuş" kampanyasıdır. Aslında bu kampanya 1928 'de başlatılmakla birlikte, $1931-32$ yıllarında İzmir'de yaşayan Yahudiler tarafından tekrar dolaşıma sokuldu. Önce taşralı Yahudiler bu çağrıya karşılık verdi, onu Kırklareli, Bursa, Ankara ve Diyarbakır Hahamları izledi. Yahudi cemaatinden sadece Türkçe konuşmaları, Türkçe isimler almaları ve içinde yaşadıkları topluma karışmaları istendi. Burada etkili olan saik, İzmir Yahudi cemaati lideri Sidi'nin, Yahudi ticaret gücünün tesisi için kamusal yaşamda Yahudilerin daha fazla söz sahibi olmalarının gerektiğine ilişkin düşüncesiydi. Daha sonraki süreçte özellikle Yahudilerin yaşadığı yerlerdeki belediyeler Türkçe dışındaki dillerin konuşulmasını yasakladılar. Yahudilerin, Türkçe 
konuşmaları konusunda yapılan bu kampanyalara olumlu cevap verip, kısa sürede uyum sağladıkları görülmektedir (Çağaptay, 2009, s. 259-260).

Türkiye'de bütün Gayrimüslimlerin yaşamını doğrudan etkileyen bir diğer, belki de en önemli mesele 1942 yılında yasalaşan Varlık Vergisi'dir. Bu verginin uygulanmasının temel nedeni, II. Cihan Harbi'nin dünya ve Türk ekonomisi üzerindeki olumsuz etkisi olmakla beraber, İttihat ve Terakki'nin 1916 yılında başlattığı milli burjuvazi inşasının Cumhuriyet dönemindeki devamı niteliğinde olmasıdır. Savaş konjonktürünün de buna imkân tanıdığını belirtmek gerekir. Yüksek oranlarda tahakkuk ettirilen vergiler için ilk etapta ev ve iş yerlerine hacizler gönderildi. Daha sonra 1943 yılında 1869 kişi tutuklandı, bunlar üçte ikisi Erzurum/Aşkale'ye çalışma kamplarına gönderildi, kalanlar ise Sirkeci'de tutuldu. 21 kişi Aşkale'deki çalışma kampında hayatlarını kaybettiler. Aşkale'den sonra 900 kişi Eskişehir/Sivrihisar'a gönderildi. 1944 yılında bu yasa yürürlükten kaldırıldı (Aktar, 2004, s. 140). Büyük kısmı İstanbul'da yaşayan Yahudi cemaati, Varlık Vergisi uygulamasından en çok etkilenen grup oldu.

Yahudilerin erken Cumhuriyet döneminde yaşadığı sıkıntılara rağmen yeni rejimi destekledikleri ve bu minvalde Kemalist akideleri kabul ettikleri de görülmektedir. Hatta yeni rejimin en ateşli destekleyicileri ve entelektüel anlamda katkı sunanlar yine Yahudi cemaati içinden çıkmıştı. Buna en iyi örnek, Ziya Gökalp ve daha sonra Kemalist elitlerle iyi ilişkileri olan Moiz Kohen ya da bilinen adıyla Tekin Alp'tir. Tekin Alp, geçirdiği ideolojik dönüşüm itibariyle Şevket Süreyya Aydemir'e benzemektedir ${ }^{1}$, ilk etapta ateşli bir Osmanlıcı iken daha sonra Türkçü ve en sonunda da Kemalist olmuştu (Berber, 2012, s. 1789). "Turan”, “Türkleştirme”, "Türk Ruhu” ve "Kemalizm” gibi eserleri kaleme alan Tekin Alp’e göre, etnik ve dini azınlıkların mutlaka Türkleşip Türk milli kimliğini her şeyin üzerinde tutmaları gerekir. Bu minvalde üyesi olduğu Yahudi cemaati için, 10 Emir'den mülhem şu önerileri dile getirmektedir: 1- İsimler Türkleşmeli, 2- Türkçe konuş, 3- Duaların bir kısmını Türkçe oku, 4- Okulları Türkleştir, 5- Çocuklarını devlet okullarına gönder, 6- Ülke işlerine katıl, 7Türklerle düşüp kalk, 8- Cemaat ruhunu kökünden sök, 9- Milli iktisat sahasında vazifeni yerine getir ve 10- Hakkını bil. Bununla birlikte ilerleyen dönemlerde, İsrail'in de kurulmasıyla birlikte Türkiye Yahudilerinin, hem milli kimliğine bağlı sadık Türkler, hem de Siyonist olabileceklerini belirtmiştir (Bali, 2009, s. 897-898). Kohen örneğinin yanı sıra, Nazi rejimi sonrası Almanya'yı terk eden Yahudi bilim adamlarının Türkiye'ye kabul edilmesi ve soykırımdan kaçan Yahudilere Türkiye'nin kapılarını açması, yeni rejimin antisemitist olmadı̆ı̆ın temel kanıtları hüviyetindedir. Zaten Türkiye Yahudilerinin Kemalist devrimleri desteklemeleri ve Türk kimliğine olan intisapları, Gayrimüslim olmalarına karşın onların Türklük dairesi içinde görülmelerini sağlamıştır. Çünkü bu dönemde Türk olmanın asıl kriteri devlete sadakat ilkesiydi ve Yahudiler, hem Kemalizmi benimsemeleri, hem de "Vatandaş Türkçe Konuş" gibi kampanyalara destek vermeleri sebebiyle bu ilkeyi yerine getirmişlerdi (Yeğen, 2006, s. 113).

\footnotetext{
${ }^{1}$ Benzer bir ideolojik geçiş Şevket Süreyya Aydemir'de de görülmüştür (Aydemir, 2016).
} 
Yahudiler arasında Resmi-Kemalist milliyetçilik anlayışı dışında kendi milliyetçilikleri, yani Siyonizm, özellikle Osmanlı İmparatorluğunun son dönemlerinde İstanbul'daki proleter Yahudiler arasında yayılmasına rağmen, Cumhuriyetle birlikte bu faaliyetlerin azaldığı gözlemlenmektedir. Gizli bir şekilde devam eden Siyonizm, Trakya Olayları ve Varlık Vergisiyle güçlendi. Açık bir şekilde 1943 yılından sonra tekrar faaliyete başlayan Siyonizm, İsrail'in kurulması ve Yahudi yayıncılığa yönelik kısıtlamaların kalkmasından sonra yükselişe geçti. Ancak İsrail'in kurulması, Türkiye Yahudilerinin yarısının göç etmesine neden oldu ve bu akım Türkiye için bir tehdit olmaktan uzaklaştı (Bali vd, 2009, s. 919-920).

\section{Kuramsal ve Metodolojik Çerçeve}

Genel olarak erken Cumhuriyet dönemindeki milliyetçilik tasavvuru -Resmi ya da Kemalist milliyetçilik- doğrudan Yahudilere yönelik olmamakla birlikte, genel olarak bütün azınlıkları Türkleştirme hedefine yönelmişti. Oysa diğer Türk milliyetçiliği tipolojilerinin Yahudilere yönelik yaklaşımları daha farklı görünmektedir. Özellikle kırklı ve yetmişli yıllar arasındaki milliyetçi-mukaddesatçı literatürde Yahudiler, maddiyatçılığın, kozmopolitliğin ve ahlaki yozlaşmanın yansıması olarak görülmektedir. Hem kapitalizmin, hem de komünizmin kurucusu olarak kabul edilen Yahudiler, "dönme" sıfatıyla Türkiye'deki sol faaliyetlerin taşıyıcı olarak telakki edilmektedir. Bu haliyle milliyetçi yazında Yahudi olgusu, Soğuk Savaş konjonktüründe solu düşmanlaştırma imgesi olarak kullanılmıştır. Resmi milliyetçilik dışındaki milliyetçilik tasavvurlarından Türkçü-Turancı milliyetçiliğin en önemli mütefekkiri Hüseyin Nihal Atsız'ın eserlerinde çok sayıda antisemitik öğe bulunmaktadır. Bora, Atsız'ın yazılarında azınlıkların aşağılayıcı bir üslupla kaleme alındığını ve Yahudilerin Türkleşmemek için gizli tedbirler alan ve Türklüğün altını oymaya çalışan dönmeler olarak kodlandığı belirtmektedir (Bora, 2009, s. 914-915). Mevcut çalışmanın temel argümanını, Bora'nın tespitinden de hareketle, Atsız'ın Türkçülük tasavvurunda antisemitizmin mühim bir öğe olduğu ve "ötekiler" olarak kurguladığı kimliklerin merkezine Yahudileri yerleştirdiği fikri oluşturmaktadır. Bu minvalde, mevcut çalışmada Atsız'ın antisemitist yazılarındaki temel saik nedir? sorusunun cevabı aranmaktadır. Bu yüzden antisemitizm olgusu ve bunun türleri bundan sonraki bölümde değinilecek, daha sonra Atsız’n Türk milliyetçiliği içindeki konumuna yer verilecektir. Bu bölümden sonra Atsız'ın yazılarındaki antisemitist öğeler analiz edilecektir. Analizler ise, eleştirel söylem analizi metoduna göre yapılacaktır. Böylece çalışmanın metodolojik çerçevesini söylem analizi oluşturacaktır. Kimlik ve farklılık kavramları, eleştirel söylem analizinin öncelikle incelediği konular olarak bilinmektedir. Söylemin kuruluşunda kullanılan temel yönelimler, ulusal kimliğin inşasına yönelik stratejiler (constructive strategies-inşacı stratejiler), ulusal kimliklerin korunması ve yeniden üretilmesi için kullanılan korumacı stratejiler, ulusal kimlikleri dönüştürücü stratejiler (transformative strategies) ve ulusal kimliklerin yapıbozumunu öneren stratejiler (destructive strategies), eleştirel söylem analizinin temelinde yer almaktadır (Yalçıner, 2011, s. 15). Elde edilen verilerin analizi, okuma\sınıflandırma, yorumlama ve yapılandırma aşamalarını kapsamaktadır. Söylem analizine ilişkin olarak verilerin değerlendirilmesi sürecinde iki farklı görüş bulunmaktadır. Bunlardan birincisi, metin içersinde kullanılan dilin özelliklerini incelemektir. İkincisi ise, metindeki baskın-dominant temaya bakmaktır (Çelik ve Ekşi, 2008, s. 111). Bu çalışmada ikinci yöntem esas alınacak; Atsız'ın 
Yusuf Ziya BÖLÜKBAŞI

kaleme aldığı metinlerdeki "Yahudi", "Mason", "Siyonizm”, "Israil” ve "Sabetaycılık -Dönme-“ sözcükleri üzerinden tema analizi yapılacaktır. Bu çerçevede mevcut çalışmayla alakalı literatür taramasında akademik veri tabanları ve yine akademik kitapların yanında Hüseyin Nihal Atsı'ın bütün eserleri de incelenmiş olup, özellikle çeşitli dergilerde yayınlanan makalelerin bir arada bulunduğu kitapları esas alınmıştır. Ancak metin içinde Atsız'ın eserlerine yapılan atıflarda dergi ve makale isimleri ve yayın tarihleri de bulunmaktadır. Buradaki amaç, Atsı'ın Yahudilerle ilgili yazılarını kaleme aldığı tarihler üzerinden antisemitist yaklaşımındaki dönemselliğin ne olduğu ve hangi saiklerden etkilendiğini ortaya çıkarmaktır. Tabi olarak, mevcut çalışmanın sınırları içinde Atsız'ın Yahudilerle ilgili bütün yazılarına yer verebilmek mümkün değildir. Bu yüzden, doğrudan Yahudiler ve Yahudiliğe ilişkin kimliklerle ilgili yazdığı yazılardan çeşitli örnekler alınması suretiyle, çalışmanın sorusuna cevap verebilecek nitelikteki söylemler analiz edilecektir.

\section{Tarihsel Bir Fenomen: Antisemitizm}

Antisemitizm, Yahudilere karşı sosyal ve politik tahrike ya da saldırganlığa verilen isimdir. Alman yazar William Marr tarafından ilk defa 1879 yılında kullanılmasına rağmen, Avrupa'da çok daha öncelerden beri var olan Yahudi düşmanlığa içkin düşüncenin dışa vurumudur (Encyclopedia of Nationalism, 2001, s. 19). Antisemitizm, tarihsel gelişimi ve geçirdiği dönüşümler itibariyle dinsel, antropolojik ve ideolojik olmak üzere üç şekilde karşımıza çıkmaktadır. Antisemitizmin ilk biçimi dinsel bir nitelik arz etmekteydi. Hristiyanlık ortaya çıktıktan sonra Yahudiler ve Hristiyanlar arasında yaşanan dinsel çatışma, on dokuz asır boyunca Yahudi düşmanlığına şekil verecek olan dinsel karakterini biçimlendirmiştir. Hristiyanlık ve Yahudilik arasında yaşanan çatışmanın özünde dinsel yorumlar bulunmakta; Yahudiler Hz. İsa'yı reddetmekte, Hristiyanlar ise kendi dinlerini evrensel bir din olarak görmekte ve Yahudilerin 'seçilmiş halk' olarak kendilerini görmelerini eleştirmektedirler. Yahudilerin ilk etapta Hristiyanlara karşı uyguladıkları baskılar, Roma İmparatorluğunun Hristiyanlığı kabul etmesiyle birlikte tam tersine dönmüştür. Ortaçağ boyunca Papaların, Yahudilere yönelik öteki mitini inşa ettikleri görülmektedir. Bu mitler Yahudileri şeytanlaştıran ve diğer insanların Yahudilerden korkmasına ve nefret etmesine neden olan sembolizasyonlara sahipti. Mesela Yahudiler şekil olarak şeytanla özdeşleştirilmekteydi, dişleri sivri, kuyrukları ve boynuzları olan, çatal tırnakları ve elleri olan yaratıklardı. Aynı zamanda Yahudiler insanlık dışı faaliyetlerin de en önemli sorumlusuydular. Kuyuları zehirliyorlar, kara büyü yapıyorlar ve ritüel cinayetleri vasıtasıyla Hristiyan çocuklarını öldürüyorlardı. Yahudileri canavarca resmeden bu yaklaşım, Yahudileri çeşitli semboller ve baskı yöntemleriyle toplumlarından dışlamaktaydı. On Sekizinci yüzyılda entelektüel değişimlerin beraberinde getirdiği Avrupa'da yaşanan aydınlanma felsefesi, Yahudilere yönelik dinsel ayrımları ve şeytanlaştırmayı bir kenara itmesi bakımından Yahudiler açısından olumlu bir gelişme olarak görüldü. Ayrıca bu süreçle birlikte kurulan ulus-devletlerde eşit haklara sahip vatandaşlara dönüşmeleri, Yahudilerin birlikte yaşadıkları toplumlarla bütünleşmelerini yeniden sağladı. Buna karşın antisemitizm form değiştirerek yeniden güçlendi. On dokuzuncu yüzyıldan itibaren antisemitizm, dinsel karakterini kaybedip yerini seküler bir kimliğe bıraktığı ifade edilebilir. Bu yüzyılın en önemli özelliği biyolojik-antropolojik çalışmalarda yaşanan artıştır. İnsanlar bu yeni bilimsel yakla- 
şımlar temelinde ırklara ayrılmakta ve ırklar arasında da bir hiyerarşi olduğu kabul edilmektedir. Bu yaklaşımlar baz alındığında Yahudiler, Sami ırklarından biri olup, aşağı ırk kategorisi içinde değerlendirilmektedir. Avrupa emperyalizmini, askeri ve öjenik yaklaşımını inşa eden Sosyal Darwinizm'e göre ırklar arasında eşitsizlik bulunmaktadır. Arthur De Gobineau'ya göre ırksal karşım, aşağı ırklar ve üstün ırklar arasında yaşanırsa olumsuz sonuçlar üretebilir. Bu yüzden aşağı ırklardan biri olan Yahudilerle Avrupalıların karışmaması gerekir (Klier, 2001, s. 1-3).

Yahudilere yönelik yaklaşımlar olumsuz yaklaşımlar seküler bir nitelik kazandıkça, onlar hakkında ortaya atılan ya da inşa edilen mitlerde değişime uğramaya başladı. İnsanlık medeniyetinin ötekisi olarak görülen Yahudiler, başta Fransız Devrimi olmak üzere 1830 ve 1848'de yaşanan devrimin arka planındaki aktörler olarak görüldü. Hür Masonlar vasıtasıyla dünyayı yönetmeye çalıştıklarına ilişkin inanç, uluslararası sermaye ağına sahip olmalarıyla güçlendirildi, hatta Üçüncü Cumhuriyet döneminde Fransa'da yaşanan Dreyfus Davası, Yahudilerin bulundukları her ülkede casusluk faaliyetleri yürüttüklerine ilişkin genel kanıyı desteklemek için kullanıldı. Yahudilere ilişkin modern mitlerin tamamı Siyonist Protokoller isimli bir kitap vasıtasıyla yayıldı. Bunların yanında 19. Yüzyıl ideolojiler çağı olarak ortaya çıktı ve bütün -izm’ler içinde belli oranlarda antisemitizmi barındırdı. Avrupa'da solu temsil eden Bruno Bauer ve Karl Marx, Yahudileri, uluslararası sermaye sahipleri ve plütokratik çağın kralları olarak isimlendiriyorlardı. Dolayısıyla sosyalist-marksist yaklaşımlar için zararlı kimselerdi. Sağ siyaset ise, Alman Nasyonel Sosyalistleri gibi, Yahudileri Bolşevik ideolojisini yeryüzüne yaymaya çalışan kimseler olarak görüyorlardı. Birinci Dünya Savaşından sonra Alman, Rus ve Avusturya-Macaristan İmparatorluğu topraklarında kurulan ulus-devletler -Polonya, Romanya, Macaristan, Belarus ve Ukrayna-, Yahudilere yönelik olumsuz yaklaşımlara sahiptiler. İkinci Dünya Savaşından sonra da antisemitizm varlığını devam ettirdi. Özellikle İsrail'in kurulması, bu yeni antisemitizm olgusunun şekillenmesinde etkili oldu. 1948 yılında İsrail'in kurulmasından sonra Araplar ve geri kalan Müslümanlar, Siyonizme karşı olduklarını dile getirip antisemitist olmadıklarını belirtmişlerdi. Dolayısıyla Araplara göre İsrail Siyonist bir projeydi ve kendileri de antisemitist değil, Antisiyonist'tiler. Sadece Müslümanlar arasında değil, SSCB'de de antisemitizm 20. Yüzyılın ikinci yarısından itibaren güçlü bir hareket olarak varlığını devam ettirdi. Stalin, Yahudileri 'Batı Emperyalizminin Ajanları' olarak gördü. Daha sonraki süreçte yüzbinlerce Yahudi Sovyetlerden İsrail'e göç etti. ABD'deki aşırı sağ ve İslami gruplar Yahudi karşıtlığını devam ettirdi. Klier’e göre, her ne olursa olsun, Yahudi düşmanlığının kaynağı pagan gelenekler ve dinden ziyade, Batılı entelektüel geleneğin devam etmesinden ibarettir (Klier, 2001, s. 3-4).

\section{Türkçü Bir Münevver: Hüseyin Nihal Atsız}

Hüseyin Nihal Atsı (1905-1975), Türk milliyetçiliğinin en kesin kalemi olması, mücadele ve çileyle geçen yaşamı, Türkçülüğün romantizmini hala birçok milliyetçinin fikirlerinde yer almasını sağlaması, tarihçi, edebiyatçı ve ideolog kimliğiyle milliyetçi literatürünün en mümtaz şahsiyeti olarak görülebilir. Bu minvalde Atsız'ın eserleri, fikirleri ve hayatıyla alakalı çok sayıda akademik çalışma kaleme alınmıştır. Atsız'ın Türkçülüğüyle alakalı olarak yapılan birkaç değerlendirmeye yer vermek elzemdir. Deliorman'a (2014, s. 170-173) göre Atsız'ın düşünce sistemi ve görüşleri iki sacayağına sahiptir: Türkçülük ve Turancılık. Sertkaya (2014, s. 121), Atsız’ın Türkçülük anlayışının 
Yusuf Ziya BÖLÜKBAŞI

şu üç bileşene sahip olduğun ifade etmektedir: Irkçlık, Turanclık ve Militarizm. Ercilasun (2018, s. 581) ise Atsız'ın Türkçülük anlayışının biri iç diğeri dış olmak üzere iki hedefi olduğunu belirtmektedir: iç hedef ırkçıık, dış hedef Turancılık'dır. Ancak, hem Sertkaya, hem de Ercilasun Atsız'ın ırkçılık kavramının biyolojik ırkçılık olarak görülmemesi gerektiğini belirtmektedirler. Nitekim Atsı'ın fikir dünyasına olumsuz yaklaşan Bora (2017, s. 279) bile Atsız'ın temsil ettiği ırkçılığın, Reha Oğuz'un biyolojik ırkçılığından ziyade metafizik bir ırkçılık olduğunu belirtmekte, Atsız'ın fikir dünyasını Türk milliyetçiliği=Türkçülük=Turancılık=Irkçılık denkleminde anlaşılabileceğini ifade etmektedir.

Atsız, iki dünya savaşı arasında, Resmi-Kemalist milliyetçilik anlayışını eleştirebilen ve buna karşı soy esasına dayalı bir Türkçülük anlayışı inşa eden Türkçü bir mütefekkir olarak görülebilir. Özellikle Türk Tarih Tezine karşı yaptığı çıkış ve 1944 Türkçülük-Turancılık Davasıyla resmi ideolojiyle çatışan Atsız, ileri sürmüş olduğu fikirleri vasıtasıyla Türkçü-Turancı milliyetçiliğin genel esaslarını çizmiştir (Bölükbaşı, 2018, s. 55-56). Atsız’ın Türkçülük anlayışını üzerine inşa ettiği yaklaşımlardan biri mevcut çalışmanın temelini oluşturması bakımından önem arz etmektedir. Bu yaklaşım zenofobi yani yabancı düşmanlığıdır. Ancak Atsız, yabancı olgusunu dışarıdan ziyade içeride aramakta, bu çerçevede etnik grupları, azınlıkları ve "Türkümsü" -Türk kökenli olmayıp kendini Türk zanneden- olan kişileri hedef almaktadır (Ertekin, 2009, s. 378). Bu gruplardan biri de Yahudiler ve kökeni Yahudi olmakla birlikte kendini Türk iddia edenlerdir. Atsız' In Yahudiler ve Yahudilikle ilgili olan kimlik-kavramlar olan, Siyonizm, Masonluk ve Sabetaycılar hakkındaki yazılarını incelemek gerekmektedir.

\section{Atsız'ın Yazılarında Yahudilik, Masonluk, Sabetayizm ve Siyonizm}

Atsız yazılarında sıklıkla Yahudilik, Dönme-Sabetayist-Selanikli, Mason ve Siyonizm kavramlarına yer verdiği görülmektedir. Ayrıca İsrail kurulduktan sonra İsrail ve Ortadoğu'da yaşanan ArapYahudi çatışmalarını da eserlerinde işlemektedir. Burada, Atsız'ın bu konularla ilgili bütün yazılarına yer vermek, akademik çalışma sınırları içinde mümkün olmadığı daha önce belirtilmişti. Bunun en önemli sebebi, bahsedilen konular hakkında Atsız külliyatının çok geniş olmasıdır. Dolayısıyla Atsız'ın, incelenen konular bağlamında önemli görülen birkaç yazısına yer verilmesi, onun Türkçülük tasavvurundaki antisemitist yaklaşımı göstermek bakımından yararlı görülmektedir. Atsı'ın yazılarına yer vermeden önce bunların sınıflandırılması ehemmiyet arz etmektedir. Genel olarak Yahudilere ilişkin sert ve olumsuz yaklaşımlar sergileyen Atsız, İsrail kurulduktan sonra bazı yazılarında, ırki açıdan Yahudileri tenkit etmeye sürdürse de, milli ülkü çerçevesinde takdir ettiği görülmektedir. Böylece Atsızın Yahudilerle ilgili yazılarını ikiye ayırarak incelemek gerekmektedir. İlk olarak, Yahudilerle ilgili yazılarının çok büyük çoğunluğunu oluşturan ırk-ideolojik yaklaşımı esas alan düşüncelerine yer verilmesi, daha sonra da İsrail'in kuruluşu çerçevesinde Yahudi örneğini takdir etme düşüncesini incelemek yararlı görülmektedir. 


\section{1. İdeolojik-Irki Yaklaşım}

Atsız eserlerinde Yahudilik konusuna genellikle ırki-ideolojik açıdan yaklaşmaktadır. Yahudilerin ırki özelliklerine antisemitist açıdan yaklaşan Atsız için Yahudiler, her zaman gizli tedbirler alarak, hem Türk milletine ve milliyetçiliğine yönelik faaliyetler yürüten, hem de Türk gibi görünmek suretiyle bu millete zarar veren bir topluluktur. Bunun yanında Atsız, Osmanlı İmparatorluğunun son dönemlerinde, Birinci Cihan Harbi ve Milli Mücadele esnasında Yahudilerin Türklere ihanet ettiklerinden de bahsetmektedir. Ayrıca Türkiye'deki Marksist ideolojinin ana aktörü ve küresel Marksizmin baş müsebbibi Yahudilerdir. Marksizmle birlikte Siyonizm ve Masonluk düşman ideolojiler olarak Atsız tarafından tanımlanmakta ve bunların hepsinin Yahudi kimliğiyle alakalı olduğu üzerinde durulmaktadır. Bu minvalde Atsız'ın birkaç makalesini incelemek gerekmektedir.

Çanakkale'ye Yürüyüş-Türkçülüğe Karşı Haçı Seferleri adlı eserinde Atsız, Yahudiler hakkında şunları ifade etmiştir:

Buradaki Yahudi de her yerde tanıdığımı Yahudi'dir. Sinsi, küstah, zelil, korkak, fakat fırsat düşkünü Yahudi; Yahudi mahallesi her yerde olduğu gibi burada da çığırtkanlığın, gürültünün ve lavsın merkezi... Çarşıdaki dükkânların levhalarını okuyoruz. Onda dokuzu bizi sinirlendiren nankör ve kahpe milletin isimlerini taşıyor. Kuvvetli olduğumuz zaman karşımızda köpekçe yaltaklanan, bozgun çağlarımızda küstahlaşıp düşmanlarımızla birleşen tarihin bu hain ve piç milletini artık aramızda yurttaş olarak görmek istemiyoruz. Cihan savaşında düşmanlarımıza casusluk eden ve bezirgânlıklarıyla kanımızı emen Yahudi tarihin hep o iki yüzlü Yahudi'sidir. Kurtuluş savaşında Bursa'ya Yunanlılar girerken kocaman bir Yunan bayrağıyla onları karşılayan fakat Türkler Bursa'yı geri alırken aynı bayrağı ordumuzun ayakları altına seren yine bu vatansız Yahudi'dir. İstanbul'da tımarhanelik bir çılgın sevdiği bir Yahudi kızını öldürdüğü zaman, kızın cenaze merasimini Türklere düşmanlık nümayişi şekline sokan ve hatta Türk ordusuna uşaklık eden (çünkü Yahudi hiç bir zaman asker olamaz) askerî üniformalıları da dâhil olduğu halde "kahrolsun Türkler" diye bağıran aynı hain Yahudilerdir. Türk'e düşmanlık bu Yahudilerin irinden kanına o kadar işlemiştir ki vaktiyle katliamlarla kovuldukları İspanya'yı ve zaman zaman kırgına uğradıkları Rusya'yı kendilerine koruyucu bilecek kadar ileri gitmişlerdir. Sanki Türkiye miskin Ispanya'dan veya salak Rusya'dan korkacak da Yahudiler hakkında yaptığı tazyiki gevşetecekmiş gibi... Evet, Yahudi şimdiye kadar hiç bir kötülük görmediği Türk'e düşmandır. Çünkü onun mayası Yahudilik, yani kahpeliktir. Türkeli'ne "eroin"i dost(?) bir milletin erkânı harbiyesi sokuyor, onun Türkiye'deki komisyonculuğunu da ermeni ve bilhassa Yahudi vatandaşlar yapmıyor mu? Büyük atalarımızın değerli savlarım unutmayalım. Onlar Yahudi'den yumurta alan içinde sarısını bulamaz demişlerdir. Bu, Yahudi'nin hilekârlığını açığa vuran büyük bir hikmettir. (2015, s: 4). 
Atsız, 20 Nisan 1951 tarihinde Orkun Dergisinin 29. Sayısında kaleme aldığı "Tarih Şuuru” isimli makalesinde Ahmet Emin Yalman ve onun nezdinde Sabetayclık-Dönmelik ve Yahudilik konularında şunları dile getirmişti:

Esefle söyleyelim ki Ahmet Emin Yalman, Türk ve Müslüman değildir. Bu vatan ve milletle ilgisi yalnız Türk pasaportu taşımaktan ve Türk tebaası olmaktan ibarettir. Ahmet Emin Yalman "Yahudi Dönmesi" yahut "Selanik Dönmesi" denilen ve on yedinci asrın sonlarına doğru Sabetay Sevi adında maceraperest ve serseri bir Yahudi tarafından kurulan gizli bir ırkî-dinî cemaate mensuptur. Mesihlik iddia eden ve mucize göstermek davasında bulunan bu çılgın Yahudi, Türk Padişahı Dördüncü Avcı Sultan Mehmet tarafından huzuruna çağrılmış ve: "Seni kurşuna dizdireceğim. Ölmemek mucizesini göster de hepimiz birden sana inanalım" hitabını alınca bütün Yahudilere has korkaklıkla padişahın ayaklarına kapanarak Müslüman olmuştur. Canını kurtarmak için yalandan Müslüman olup Mehmet adını alan bu münafık Yahudi, güya bütün Yahudileri de Müslüman etmek gibi yüksek ve dini bir vazifeyi üzerine alarak Türkiye'nin türlü bölgelerinde dolaşmış ve son yüzyılların bütün sahte peygamberleri gibi Rasputinizm ahlâksızlığına da saplanarak bugün kısaca "Dönme" dediğimiz cemaatin temellerini atmıştır. Sabetay Sevi öldüğü zaman Selânik'te 200 Yahudi ailesi onun bu gizli dinine girmiş bulunuyordu. Dışarıya karşı gayet kapalı olan bu cemaat sıkı bir dayanışma ile günümüze kadar gelmiştir. Bunlar yalnız kendi aralarında evlenirler. Zahirî Müslüman isimlerinden başka gizli Yahudi adları taşırlar. Müslümanlarınkinden farklı olarak Yahudiler tarzında sünnet edilirler. Ölülerini ayrı mezarlara gömer ve mezar başında gizli Yahudi âyini yaparlar. Dönmeler kendi aralarında "Hâdibeyler", "Karakaşlar", "Kapancılar" adında üç kola ve âdeta üç oymağa ayrılırlar ki bu, onların hiyerarşisidir. Kendilerine mahsus bayramları vardır. Bu bayramlardan 22 Martta yapılan "Kuzu Bayramı" yahut (Dört Gönül Bayramı) en korkuncudur. Dönmeliğin iç yüzünü anlatan ve Ibrahim Alâettin tarafından yazılan "Sabetay Sevi" adlı kitapta bu bayram şöyle anlatılıyor: Bu kuzu bayramı hakkında Sabetay zümresi mensuplarından Karakaşzade Rüştü, 1924 tarihinde "Vakit" gazetesi muharririne şu izahatı vermişti: Kuzu bayramı 22 adar (Mart)da yapılır. Bu bayram geceye mahsustur. Ve her sene kuzu eti ilk defa bu bayram münasebetiyle ve hususi merasimle yenir. Bu merasimde en aşağı ikisi erkek, ikisi kadın olmak şartıyla evli dört kişinin bulunması lazımdır. Kuzu ziyafetinde bulunacakların sayısı iki cinse mensup evli çiftlerin arttırılması şartı ile istenildiği kadar çoğaltılabilir. Kadınlar iyi giyinmiş ve elmaslarıla süslenmiş oldukları halde sofra hizmetinde bulunurlar. Yemekten sonra biraz eğlenilir ve muayyen zamanda ışıklar söndürülerek karanlıkta kalınır... Bu bayram vesilesiyle doğacak çocuklar bir nevi kutsiyeti haiz tanınırlar. Ona "Dört Gönül Bayramı" adı verilir (1992a, s. 41-42). 
Aynı yazının devamında Atsız şunları ifade etmektedir:

İste bugün Türk basının kodamanlarından olan ve bütün millî meseleler hakkında fikirler beyan eden, Türklük-Müslümanlık dâvasının her safhasına karışan, Başbakan Adnan Menderes gibi aşağı yukarı müttefikten sevilen bir devlet adamını, irticai korumakla suçlandıran adam bu cemaate mensuptur. Deniz Binbaşısı İstanbullu merhum Mehmet Nail Bey'in oğlu, Deniz Kolağası (Ön yüzbaşısı) Dorul'lu Merhum Hüseyin Efendinin torunu olan beni ve kardeşim Nejdet Sançarı, yani bu toprağa ve ırka atalar, dedeler kanı ve hâtırasıyla bağlı insanları, "millî varlığımızın temellerini kundaklamakla suçlayan adam budur: Selânikli Ahmet Emin Yalman! Millî menfaati o yolda gördükleri için "devletin başında halis Türkler bulunmalıdır" diyen milliyetçileri "ırkçılar, nazistler" diye gözden düşürmeğe, onları âdeta vatan haini gibi göstermeğe yeltenen adam bu gizli Yahudi ırkçısı Ahmet Emin'dir. Millî meseleleri konuşuyormuş gibi gözükerek memlekette tahrikat yapan ve nihayet bu yüzden aleyhinde takibata başlanan, başbakana: "Allah onunla dost olmaktan beni korusun" dedirten bu Ahmet Emin'i, Yahudiliğine bağışlayarak mazur görebilirdik. Fakat biz onun mazisini de biliyoruz. Bir zamanlar Türkiye'nin Amerikan mandasına girmesini istediğini, doğu illerimizden bazılarını Ermeniler'e vermek teklifinde bulunduğunu, Türkiye'deki azınlıkları gücendirir diye "Türk" adını taşımayıp "Osmanlı" kelimesini kullanmamı gerektiğini, Ruslar'a teminat vererek onlarla anlaşmamızın büyük bir siyasi şart olduğunu hiç sıkılmadan, utanmadan yazdığını da biliyoruz. Daha dün denecek kadar yakın bir geçmişte komünist Nâzım Hikmet'in büyük bir vatanperver olduğunu yazması gibi vicdan hâilelerini bir tarafa bırakarak eski yazılarından parçalar alalım... Bütün bunlar kendisine gösterildikten sonra bile, Ahmet Emin'in, hiçbir şey olmamış gibi, yurtseverlik dersi vermekte devam edeceğine eminim. Fakat acaba, bunları gördükten sonra, Ahmet Emin'in şahsında doğru görüşlü bir memleket evladı (!) bulduklarını sanan bazı Türk gençleri ne yapacaklardır? Ahmet Emin'le ağız birliği ederek ötede beride bana sövdükleri için pişmanlık duymak faziletini gösterecekler mi, yoksa Türk vatanını ve istiklâlini peşkeş çeken o "Dönek Dönme" ile aynı safta kalmakta devam mı edecekler? Ben vaktiyle resmî ağızlardan bile vatan hainliği iftirasına uğrarken perdenin arkasında veya önünde yine aynı devşirme ruhu ile cemaatlerinin karakterini yukarda kısaca anlattığım aynı dönmelik vardı. Dönmeliğin basındaki mümessili bugün Ahmet Emin'dir. Onun maksadı: Aşağı yukarı yirmi bin kişilik gizli Yahudi dönmesi cemaatinin Türkiye'ye manen, iktisaden ve belki de maddeten hakim olmasıdır. Bu gayeye doğru plânlı bir şekilde ilerlemektedirler. Bugün hepsi refah içindedir. Aralarından bir çoğu profesör, öğretmen, gazeteci, doktor ve avukattır. Çoğu zengin tüccardır ve ticarethanelerinde yalnız kendi ırkından insanlar çalışmaktadır. 1943 'te aralarında verdikleri karar gereğince Türkiye'nin şimdilik yüksek kültür mevkilerini işgale uğraşmaktadırlar. içlerinde askerî doktor vardır, fakat harp sınıfından subay yoktur. Ahmet Emin'in mütemadiyen dönmesi, menfaat rüzgârlarına uymak içindir. Daima daha zengin, daha yüksek mevkide olmak için cemaat kanunları 
gereğince bunlar mubahtır. Benim aleyhimde yazması, sırf millî tarih şuurunu uyandıracak bir iki yazı yazdığım içindir. Kandırdıkları ve kendilerine uydurdukları bazı gafillerle birlikte Türkçülüğe ve mukaddesata karşı dönmelerin açtığı savaş, onlar için Türklük arasında erimemek, Yahudi dönmesi cemaatini korumak davasıdır. Bunu açıkça söylemek imkânına mâlik olmadıklarından dolayı daima dolambaçlı yollardan gidiyorlar ve devrin geçer akçası ne ise onu kullanmaktan geri kalmıyorlar. Türk vatanında Ahmet Emin gibi bir "Yahudi dönmesi" benim gibi bir "TÜRK"ü millî varlığın temellerini kundaklamakla suçlandırıyor. Baht utansın! (1992a, s: 42-44).

Atsız, 25 Temmuz 1968 tarihinde Ötüken dergisinin 8. Sayısında yayınlanan “Solun 94 Yılı” makalesinde şunları belirtmişti:

Türkiye Komünist Partisine başkanlık edenlerden en mühimi ve körü körüne Rusya taraftarı olan ikincisi Doktor Şefik Hüsnü Değmer ve Nazım Hikmet Verzanski'dir. Tuhaf bir tesadüfle bunların ikisi de Türk menşeli değildir. Şefik Hüsnü, Selanikli Yahudi dönmesi; Nazım Hikmet ise Polonyalıdır. Acaba Şefik Hüsnü ve Nazmı Hikmet Türk soyundan olmadıkları, kendilerini Türk duymadıkları için mi bu milletin bekası ile hiç ilgili görünmüyorlar? Bu konu, üzerinde durulmaya değecek kadar mühimdir. Bir etüt olarak işlenmelidir. En mutaassıp komünistlerden Sabıka Zekeriya'nın da bir Selanik Yahudi dönmesi oluşu, adları sayılanlar arasında Gayrı Türkler'in bir hayli bulunuşu dikkatten kaçacak gibi değildir (1992a, s. 146)

Orhun dergisinin 16 Temmuz 1934 tarihinde yayınlanan 9. Sayısında yer alan "Türk Irkı=Türk Milleti” makalesinde Atsız, Yahudiler ve Türkler arasında şu mukayeseyi yapmaktadır:

Türk olmak için Türk ırkının maddi ve manevi hasletlerini tevarüs etmek icap eder. Binlerce yıllık tarihi hayatların milletlere verdiği bir terbiye vardır ki o öyle bir kaç yılda ve hatta asırda elde edilemez. Asırlardan beri kılı̧̧ sallamış ve ömrünü er meydanında geçirmiş Türk milletinin bir çocuğu ile asırlardan beri sahtekârlık ve dolandırıcılıkla, yaşamış Yahudi milletinin bir çocuğu nasıl müsavi olabilir? Aynı günde doğan bir Türk çocuğu ile bir Yahudi çocuğunu aynı terbiye müessesesine alıp ikisine de yalnız Esperanto dili öğretseler ve aynı şartlar altında aynı terbiyeyi verseler bile muhakkak ki Türk çocuğu yine yiğit, Yahudi yine korkak olacaktır. Türk çocuğu yine doğru, Yahudi Yine sahtekâr yetişecektir. Bazılarının söylediği gibi milliyet yalnız anlaşma vasıtası olan dil'in birliği ile izah edilseydi bir İstanbul Yahudi'sinin bize bir Kırgız'dan daha yakın olması lazım gelirdi. Hâlbuki bütün kanunlara, siyasi ve içtimai hadiselere, propagandalara rağmen biz Kırgız'ı kardeş, Yahudi'yi de köpek çıfıt olarak tanıyoruz. Çünkü Kırgız'ın damarındaki kanın kendi damarımızdaki kan olduğunu, Yahudi'nin ise bize düşmanlıkla yoğurulduğunu biliyor, seziyoruz. Türk milliyetinde menfaat birliği meselesi ise ağza bile alınamaz. "Ayın çanaktan yalayanların bir millet olduğu" hakkındaki düşünceleri reddettikten sonra menfaat birliği solda sıfır 
kalır. Bir Kazakla bir Konyalının menfaatlerinde ne birlik vardır? Hâlbuki bunlar bir milletin çocuklarıdır. Bir Erzurumlu ile bir Izmirlinin menfaatleri arasında da bir iştirak yoktur. Her ne kadar bazı Marksistler Kurtuluş Savaşını iktisadi bir hareket olarak izah etmek gibi Yahudice düşünüyorlarsa da Erzurumlu askerin Izmir için ölmesi kendi istihsal maddelerinin ihraç iskelesi olan Izmir'i kaybetmek, kaygısı dolayısıyla değildir. Bu tamamı ile duyguya ait bir meseledir; bir kan meselesidir (1992b, s. 56-57).

Çanakkale'ye Yürüyüş-Türkçülüğe Karşı Haçlı Seferleri adlı eserinde Atsız, Selanik Dönmesi olarak adlandırdığı Sabetayistler hakkında şunları dile getirmişti:

Düşüncemde pek de haksı değildim. Çünkü 200 aileden kurulu olan Selanik dönmeleri aşağı yukarı üç yüz yıldan beri hep kendi aralarında evlene evlene tıbbın da akrabalar arasında boyuna evlenenler için kabul ettiği gibi bozulmuşlar, soysuzlaşmışlardı. Her dönme kusurlu, sakat ve anormaldi. Hattâ bizim mahdum beylerin doğduğu Alman hastanesinin hepsi de uzman olan hemşireleri, dönme kadınlarının yaptığı doğumlarda çok ölüm veya anormal doğuş olduğunu söylemişlerdi. Benim hakkımda hüküm verecek değildi ama ortada elbette benim anlayamadığım bir hukuk inceliği vardı. Tayin ettiği günde yine gittim ve bu sefer hiç bekletilmedim. Karşımda isterik, megaloman bir adam buldum. Bana faşistlik isnadının nereden geldiğini de öğrendim: Selanik dönmelerinin kurduğu bir lise olan Boğaziçi Lisesinde birçok da dönme öğretmen bulunuyordu. Bunların arasında müdür Hıfzı Tevfik gibi Türkleşmiş, Türklüğü seven, hattâ diğer bir dönme hocadan bahsederken: "Sen bilmezsin, o ne domuz Selâniklidir" diyenleri! bulunduğu gibi hakikaten domuzuna Yahudi olanları da vardı. Hattâ bunlardan birinin babası, İstiklal Savaşının sonundaki nüfus değişiminde, Türkiye'ye gelmeyerek Selânik'te kalmak için Yunan hükümetine başvurarak kendilerinin Türk ve Müslüman olmadıklarını iddia etmişti. Benim faşistliğim bu dostların telkininden geliyordu. Onlar da, hamam böceği de dönme değil mi, hepsi birbiriyle akraba idiler. Tabiî, Boğaziçi Lisesi öğretmenler odasındaki konuşmalar, sıkıyönetim yargıcına başka türlü aksettirilmişti. Yargıç da bana rahmet okuyacak değildi ya... Ne de olsa dönme idi. Yani buz gibi Yahudi. Hem de bildiğimiz Yahudi'den daha koyu Yahudi. Hiç şüphesiz benim Yahudiler hakkındaki düşüncelerimi de biliyordu. Almanlar girdikleri yerde Yahudi bırakmadıkları için dönmeler tarafından sevilmelerine imkân yoktu. Bu yüzden onların Rusya'daki zaferlerinden hoşlanmıyorlar, aramızdaki aykırılık buradan doğuyordu. Selanik dönmesi olan sıkıyönetim yargıcına "faşist" diye jurnal edilmemin sebebi de bu idi. Alman çekilişi başladığı zamanki sevinçlerine ise son yoktu (2015, s. 18-20).

Atsız, Atatürk'e karşı tertip edilen suikast girişimiyle alakalı yazısında Masonluk ve dönmelik konularında şunları belirtmektedir:

Ittihatçılar daha sonra Izmir suikastı ile Mustafa Kemal Paşayı yok etmek istemişler, fakat kendileri yok olmuşlardı. İste bu sebeplerle Mustafa Kemal Paşa ittihat- 
çılardan nefret ediyordu. Kendisine suikastı hazırlayan şebekenin başında olduğu için asılan Selânikli Yahudi dönmesi Cavit'in idamı dünya basınında büyük tepki uyandırmıştı. Çünkü Cavit hem Yahudi, hem de farmasondu. Fakat Mustafa Kemal Paşa kabadayı adamdı. Dünya gazetelerinin ulumasına aldıracak tiplerden değildi. Cavit'i astırdığı gibi mason localarını da kapatmaktan çekinmedi. Bu da Mustafa Kemal Paşa'nın en müspet icraatından biridir. Çünkü bu localarda mason kardeşliği adına devletin en gizli işlerini Yahudiler, Rumlar ve Ermeniler öğreniyor ve bunların hepsi yabancı casusu olduğundan düşmanlarımızca bilinmedik devlet sırı kalmıyordu (2015, s. 79).

Yahudilerin Birinci Cihan Harbinde Kanal Cephesindeki ihanetini Atsı şöyle ifade etmektedir:

Türkiye için en doğru askerî düşünce evvelâ memleketteki beşinci kolu imha etmektir. Türk ordusu geriden vurulmadıkça yenilmesi güç olan ordulardan biridir. Birinci Cihan Harbinde, Sarıkamış faciasına rağmen Ruslara karşı, sayıca çok az olduğu halde basan ile çarpışan ordumuzun, Ermeniler tarafından arkadan vurulduktan sonraki hali, keza Filistin cephesinde ikinci bir Çanakkale yaratan Yıldırım Orduları grubunun Araplar ve Yahudiler tarafından ihanete uğradıktan sonra ne hale girdiği düşünülsün (1992c, s. 100).

Atsız, Orhun dergisinin 1934 tarihli 7. sayısında yayımlanan ve doğrudan Yahudi konusunu ele alan “Musa'nın Necip Evlatları Bilsinler Ki” adlı makalesinde şunları dile getirmektedir:

Yahudi denilen mahlûku dünyada Yahudi'den ve sütü bozuklardan başka hiç kimse sevmez. Çünkü insanlık daima kuvvete, kahramanlığa ve iyiliğe tapındığı halde Yahudi zilletin, korkaklığın, kötülüğün ve seciyesizliğin örneği olmuştur. Dilimizdeki 'Yahudi gibi", "çıfıtık etme", "çıfıt çarşısı", "havraya benzemek", "Yahudi'den yumurta alan içinde sarısını bulamaz" gibi sözler bu alçak millete ırkımızın verdiği değeri gösterir. Bu yalnı bizim memleketimizde böyle değildir. Almanya'dan kovulan Yahudileri kabul etmek misafirperverliğinde bulunan Fransa'da bile Yahudiler hakkındaki en basit iltifatın "pis Yahudi" terkibi olduğunu o memlekete gitmiş olan arkadaşlarımız söylüyor. Almanya, Lehistan, Macaristan, Romanya gibi bazı memleketlerde ise Yahudi aleyhtarlığının nasıl yırtıı bir şekil aldığını ve bir gün bu memleketlerdeki Yahudilerin muhakkak kapı dışarı edileceğini hepimiz biliyoruz. Yahudi meselesini ilk halleden memleket Almanya olmuştur. Başka milletler bundan ders alacaklardır. Isveç gibi kendi halinde bir milletin bile Yahudi düşmanı olması bu menfur milletin bütün dünyada nasıl telâkki olunduğunu ispat etse gerektir. İstanbul'da çıkmaya başlayan Millî inkılâp mecmuasının Yahudilerin hakiki mahiyetini meydana koyan neşriyatı üzerine Yahudiler arasında bir galeyan olduğunu, hattâ onların Beyoğlu'nda gizli bir toplantı yaparak Milî inkılâp mecmuasına karşı mukabil cephe almak için bazı kararlar verdiklerini işittik. Yalnız bu hareketleri bile onların Türkiye'ye karşı besledik- 
leri duyguları gösterir. Bir defa hükümetten gizli olarak toplantı yapmak kanunî bir cürümdür. Müddei umumiliğin dikkatini celbederiz. Saniyen kendi aleyhlerinde neşriyat yapılmamasını istiyorlarsa bu vatana sadık kalmağa mecburdurlar. Onlar her hareketleriyle ve çıfıt yaygaralarıly bizden ayrı olduklarını daima bize anlatırlarken biz de herhalde onlara methiye yazacak değiliz. Biz Yahudilerin memleketteki meşum iktisadî ve ahlâkî rolünü biliyoruz. Hattâ mütareke yıllarında İstanbul'u süsleyen (!) ingiliz, Fransız, Amerikan, Italyan, Yunan ve Ermeni bayrakları arasında bir de Yahudi bayrağı olduğunu unutmadık. Eliza Niyego adındaki Yahudi kızının cenaze merasiminde yaptıkları edepsizliği de kendileri unutmamışlardır. Bir maliye memuruna rüşvet teklif ederken Ankara'da yakalanan iki Yahudi avukatla, Türklügü tahkir yüzünden tevkif olunan Yahudi kızı meseleleri de onların namussuzluklarının son perdesini teşkil ediyor. Öyle, ikide bir Yahudileri Türkleştirme cemiyetleri kurarak bizi kandırmağa çalışacaklarına namuslu Türk tebaası olarak kalsınlar yetişir. Çünkü biz onların Türkleşeceklerini asla unutmadığımız gibi bunu istemeyiz de. Çamur ne kadar fırına verilse demir olmayacağı gibi Yahudi de ne kadar yırtınsa Türk olamaz. Türklük bir imtiyazdır, her kula, bilhassa Yahudi gibi kullara nasip olmaz. Onlara yapılacak ihtar şudur: Hadlerini bilsinler. Sonra biz kizarsak Almanlar gibi Yahudileri imha etmekle kalmaz, daha ileri giderek: onları korkuturuz. Malûm ya ataların sözüne göre Yahudi'yi öldürmektense korkutmak yektir (1992c, s. 214-215).

Masonluk, Siyonizm ve Komünizmi ortak düşman olarak gören Atsız, Orkun dergisinin 18 Ocak 1952 tarihinde yayınlanan 68. Sayısındaki “Veda” başlıklı yazısında şunları dile getirmişti:

Masonluğu da düşman sayıyoruz. Kökü dışarıda olan gizli bir cemiyettir ve milliyetçilikle tatmin olunmayanların başvurduğu Türkçülük düşmanı bir teşekküldür. Başlangıçta Yahudilerin millî menfaatlerini gizli olarak korumak için kurulmuş, zamanla beynelmilel bir hale gelmiştir. Savaş halinde bulunan iki millete mensup Masonların, kendi devletleri aleyhine olsa bile' birbirlerine yardım etmek mecburiyetinde olmaları bu zümrenin bütün milliyetçiliklere ve bu Türk milliyetçiliğine de düşman olduğunu göstermektedir. Onlar gizlice her yere el atıp orayı ele geçirmeğe çalışmakta ve muvaffak olmaktadır. Bugünkü "Türk Ocağı"nın umumi idaresi ihtiyar Masonların elindedir ve bu yüzden, vaktiyle milliyetçiliğe o kadar hizmet etmiş bulunan bu müessese artık hizmet edememektedir. Siyonizm, Yahudi ırkının huzurunu dünya milletlerinin huzursuzluğunda arayan teşkilâtı bir insanlık düşmanı fikirdir. Kendisini bir devletin milli ülküsü göstermek yolundaki gayreti emperyalist arzularını gizlemek içindir. Birinci Cihan Savaşında, her türlü kılığa girerek Filistin Cephesindeki ordumuzu arkadan vuran ve düşmana casusluk eden Siyonistlerin ortaya koyduğu korkunç hakikat, Türkçüleri bu cereyana karşı da her zaman uyanık ve tedbirli bulunmaya sevk etmektedir. Komünizm, Siyonizm ve Masonluk Türkiye'de bir sacayak halinde Türk düşmanlığı yapmaktadır (1992b, s. 41). 
Atsız, Ötüken dergisinin 22 Kasım 1970 yılında yayımlanan 12. Sayısında yer alan "Komünist, Yahudi ve Dalkavuk" adlı makalesinde Yahudilerle ilgili şu düşüncelere yer vermektedir:

Türk milletinin dışarıdaki düşmanları bütün dünyadır. Bunu tarih bize ebedî bir ögüt halinde hikâye eder. İçerideki düşmanları ise üç tanedir: Komünist, Yahudi ve dalkavuk. Komünist, vicdanını Yahudi "Marks"a satmış olan vatansız serseri demektir. Amele diktatörlüğünün kurulduğu yerde cennete varılmıs olduğunu zanneder. $O$, bazen bu zannında samimî olan bir aptaldır. Bazen de samimî değildir, aldatmak için böyle söyler. O zaman da kalleştir. Komünist, dünyada patronla işçi arasındaki hukuk müsavatsızlığını halletmek için ortaya atıldığını söyler. Bunun için de ilk yaptığı iş dinleri, milliyetleri, vatanları inkâr etmektir._ikinci düşman Yahudi'dir. Onun Allah'ı paradır. $O$, cebine birkaç para koyabilmek için gölgesinde yaşadığı bayrağı satmaktan çekinmeyen namussuz bir bezirgandır. Hangi memlekette oturuyorsa oranın düşmanıdır. Fakat bu düşmanlığını açıkça değil yüze gülerek, tezellül ederek yapar. Yahudi mayi gibidir. Derhal bulunduğu kabın şeklini alır. Yer yer kurulan Yahudileri Türkleştirmek cemiyetleri bu zelil politikanın neticesidir. Bununla cihan savaşında düşmanlarımıza casusluk ettiklerini, mütarekede Türklüğü tahkir ettiklerini unutturmak isterler. Hattâ daha ileri giderek kendilerine Türk adları takarlar [1]. Yahudi iki türlüdür. Biri asıl Yahudi'dir, bu dilinden tanınır. Biri de Yahudi dönmesidir. Bu dilinden tanınmaz. Bunu tanımak için yüzünün mütereddi Yahudi hatlarına dikkatle bakmak lâzımdır. Yahudi'yle Yahudi dönmesinin hiçbir farkı yoktur. Biri "biz Yahudiler" derse öteki de "Siz Türkler" der. [1] Gazetelerin birinde bir Yahudi mektebinde Yahudilerin Türkleşmeye (!) karar vererek adlarını değiştirdikleri, bazıların da Atilla, Çingiz, gibi kahramanların adlarını takındıkları yazılmıştı. Zavallı Atilla, talihsiz Çingiz! Kim bilir mezarlarında nasıl bir öfke ve tiksinti ile titremişlerdir. Bir Yahudi'de Çingiz'in veya Atilla'nın kahraman adı! Yahudi ve kahraman, birbirine ne kadar yakışmayan iki söz. Eğer gazetenin verdiği bu haber doğrusu ise hükümet buna derhal engel olmalıdır. Çünkü bu birçok Türk'ü Türklükten istifa ettirecek kadar mühim bir sebeptir (1992c, s. 69-71).

Atsız, Yahudiler, Masonlar ve Komünistlerin İslam ve Türkçülüğe yönelik saldırılarını, 9 Şubat 1951'de yayınlanan Orkun dergisinin 19. Sayısındaki "Faruk Nafiz'e Bir ihtar" makalesinde şu şekilde izah etmektedir:

Komünistlerin, Masonların, Yahudilerin, Gayrı Türklerin elinde olan basın, Müslümanlıkla birlikte Türkçülüğe de şiddetle taarruz ediyor. Bu taarruzların bazılarını tabii karşılamak gerektiğini biliyoruz. Mesela Yahudi Dönmesi Ahmet Emin'in, hani mütarekede Amerikan mandasını millete tavsiye eden şu Selanikli Ahmet Emin'in, Nazım Hikmetof Yoldaşın halis bir yurtsever olduğunu günlerce yazan Halisüddem Yahudi Ahmet Emin'in Türkçülüğe sinsi veya açık hücum etmesi gayet normaldir. Biz bilakis, Tanrı göstermesin onun Türkçülüğe taraftar gözükmesinden korkarı (1992b, s. 23). 
Atsız, eserlerinin büyük bölümünde Yahudilerle alakalı ideolojik-ırki yakıştırmalar ve değerlendirmeler yapmakta; küresel antisemitizme uygun bir dil kullanmaktadır. Atsız için Yahudiler, sahtekâr, dolandırıcı, yalancı, korkak, seciyesiz, sinsi, küstah, kötü ve hain bir topluluktur. Bu konuda tarihsel analojilere de başvuran Atsız, "Çıfıt" ve "Çıfıt Çarşısı" gibi terimleri de kullanmak suretiyle Yahudilere yönelik nefretin mazisine de atıf yapmaktadır. Hatta Atsız, Yahudiler içim domuz, köpek ve hamam böceği gibi benzetmeler de yapmaktadır. Atsız'ın soy esaslı milliyetçilik tasavvuru için Yahudi, hem ırki, hem de ideolojik anlamda bir öteki konumundadır. Irki anlamda Yahudileri düşman olarak kodlayan Atsız, onların hiçbir zaman gerçek anlamda Türk olamayacaklarını belirtmektedir zira Türklük bir kan meselesidir ve Yahudiler -Yahudi ve Kırgız ya da aynı terbiyeyi alan Yahudi ile Türk çocuğu örneklerinden hareketle- Türk kanına sahip değillerdir. Atsız, Yahudilerin isteseler bile Türk olamayacaklarını belirtmektedir, çünkü nasıl ki çamurdan demir olmazsa, Yahudi'den de Türk olamaz. Nitekim Yahudilerin Türkleşmelerinden ziyade devlete sadık olmalarını yeterli gören Atsız, Türk tarihinin büyük İmparatorlarının adını almak suretiyle Türkleşmeye çalışan Yahudilere bu isimlerin yakışmayacağını dile getirmektedir çünkü onun için Yahudilik ve kahramanlı yan yana gelemez. Zaten Atsız'a göre Cengiz Han ya da Atilla gibi büyük kahramanlar, isimlerini Yahudiler tarafından alındığını öğrenmeleri halinde öfke ve tiksinti duyacaktır, bu durum, Atsız'ın metaforik betimlerle Yahudilerin Türkleşemeyeceğine ve Türkleşmemesi gerektiğine verdiği örneklerden biri hüviyetindedir. Bu minvalde Atsız'ın en çok üzerinde durduğu konu "Dönme" ya da "Selanikli" olarak isimlendirdiği Sabetayistlerdir. Bu grup hakkında tarihsel malumatlar sunan Atsız'a göre Sabetayistler, Türklük ve Türkçülüğe düşmanlardır. Ahmet Emin Yalman ile yaşadığı münakaşa üzerinden yaptığı değerlendirmelerde Atsız'ın Sabetayistleri en tehlikeli yapıların başında gördüğü söylenebilir. Çünkü bu grup gizli tedbirler almak suretiyle Türkleşmemekte ancak Türk ve Müslüman gibi görünüp bu milletin kimliğine ve dinine saldırmaktadırlar. Ayrıca Atsız’a göre, iktisadi, kültürel ve bürokratik alanlarda üst mevkileri elinde tutan bu grup, Türkiye düşmanlarıyla işbirliği yapmakta ve sürekli hedef tahtasına Türkçüleri ve Türk milletini koymaktadır. Atsı'ın Sabetayistlere karşı öjenik yaklaşımlara sahip olduğu da görülmektedir. Sabetayistlerin sürekli kendi aralarında evlenen kapalı bir yapıya sahip olmalarını eleştiren Atsız, bu durumun sağlıksız doğumlara neden olduğunu ve kusurlu nesiller dünyaya getirdiklerini belirtmektedir.

Yahudiler Atsız’a göre hiçbir kötülük görmedikleri Türk milletine tarih boyunca ihanet etmişlerdi. Birinci Cihan Harbinde Filistin Cephesinde Araplarla birlikte Osmanlı'ya ihanet eden Yahudiler, işgal yıllarında da İstanbul ve Bursa gibi şehirlerde ihanetlerine devam etmiş, işgalci güçlerin bayraklarını ilk onlar açmışlar, hatta işgalci güçlerin bayraklarının yanında kendi bayraklarını da asmışlardır. Ancak Milli Mücadele başarıya ulaşınca Yahudiler, Atsız'a göre kendi doğalarına uygun davranarak bu sefer Türk hükümeti yanında yer almışlardır. Yahudilerin ihanetleri Cumhuriyet kurulduktan sonra da devam etmiş, Atatürk'e suikast girişiminde bulunanların başında Yahudi-Masonlar gelmiştir. Nitekim entelektüel camiayı elinde tutan Sabetayistler, yaydığı fikirlerle Atsız'a göre vatana ihanete devam etmektedirler. Bu ihanetlerinin başında Türkiye'yi Sovyet uydusu haline getirmeye çalışmak, işgal yıllarında ABD mandasının kabulü talepleri, tarihsel kavgalarımızın bulunduğu Ermenistan gibi ülkelerle işbirliği yapılmasını önermek, Türk kimliği yerine Osmanlı kimliğini kullanmak ve Türkçülüğe saldırmak bulunmaktadır. Bütün bunlarla beraber Atsız için Yahudiler bütün 
Yusuf Ziya BÖLÜKBAŞI

dünyada sevilmeyen bir millettir ve küresel anlamda yaşanan en büyük sorunların başında gelmektedirler. Atsız, bu sorunu ilk çözen milletin Almanlar olduğunu ifade etmiştir. Diğer milletlerinde Almanları takip edeceğini belirten Atsız’a göre Yahudileri öldürmekten ziyade korkutmak gerekir. Burada Atsız'ın "Yahudi sorununu çözen ilk millet Almanlar olmuştur” sözünü 1934'de dile getirdiğini belirtmek yararlı görülmektedir çünkü bu tarihte Yahudi Soykırımı yani Holokost daha yaşanmamıştı ve bu olay vuku bulduktan sonra Atsız'ın bu konuyla alakalı hiçbir şey yazmadığının altı çizilmelidir.

Atsız, Komünizm, Masonluk, Siyonizm ve bunların hepsini tek başına temsil eden Yahudiliği başlıca düşman olarak kategorileştirmiştir. Bütün bu akımlar Türkçülüğe saldırmak suretiyle yok etmek istemektedirler. Atsı'a göre Masonluk, Yahudiliğe ait gizli bir cemiyet olup amacı dünya sathında iktidar sahibi olmaktır. Türkiye'de de Türkçülüğe karşı hareket eden Masonluğun, Türk Ocağı gibi geçmişte Türk milliyetçiliğine hizmet eden bir kuruluşu ele geçirmek suretiyle Türkçülüğe zarar verebildiği, Atsız tarafından dile getirilmektedir. Siyonizm ise ona göre Yahudi emperyalizminin ideolojisi olup, Birinci Cihan Harbi döneminde Filistin Cephesinde Osmanlı'nın mağlup olmasına neden olmuştur. "Yahudice" düşünmenin ve bir Yahudi olan Marks'ın ürünü olan Komünizm ise Türkçülük için en büyük ve mühim tehlikeyi olduğunu Atsız ifade etmektedir. Dolayısıyla bütün bu düşüncelerin ana odağını Yahudilik oluşturmaktadır. Yahudileri, kendi ceplerini doldurma telaşında olan ve bu çerçevede bulundukları ülkelere rahatlıkla ihanet edebilen insanlar olarak gören Atsız, Yahudilik, Komünizm, Masonluk ve Siyonizmi düşman kimlikler ve ideolojiler olarak kategorileştirmektedir. Çünkü ona göre bütün bu akımlar ve kimlikler, Türklük, İslamiyet ve Türkçülüğe karşı bir bütün olarak hareket etmekte ve bizi yok etmek istemektedirler.

\subsection{Milli Ülkü Nosyonu Üzerinden Yahudi Yaklaşımı}

Eserlerinin çok büyük bir bölümünde Atsız, Yahudilere yönelik ideolojik-ırki açıdan yaklaşıp açık bir antisemitizm örneği sunsa da, Yahudilerin kendi milli ülküleri peşinde koşmalarını takdirle karşılamakta ve Türkçü-Turancı ideallerini bu konu üzerinden meşrulaştırmaktadır. Ancak bunu yaparken yine Yahudilere ilişkin ırki yaklaşımları bırakmayan Atsız, Arap-İsrail savaşına ilişkin çeşitli analizler yapmakta ve İsrail tehdidine dikkat çekmektedir.

Atsız, "Ordinaryüsün Fahiş Yanlışları" isimli makalesinde Yahudiler hakkında şunları ifade etmektedir:

Uzun zamanların ve mesafelerin ayırması bile bir milletin parçalarını tek millet olmak tan çıkarır mı? Çıkarırsa bu İsrail Yahudileri nerden peydahlandı? iki bin yıldan beri ne dil, ne vatan, ne ırk, ne gelenek... Hiçbir ortaklaşa tarafları kalmamış, yalnız milli dinleri ile milli inançları elden gitmemişti. Irlanda, Fransa, Bulgaristan, Türkiye, Suriye ve Yemen'den gelen bu tip tip ve dil dil Yahudiler tek millet oluyor da ben neden esas bakımından aynı dili konuşan Tebrizli veya Genceli, neden Kırımlı veya Kazanlı, Taşkentli, Kaşgarlı veya Kulcalı ile hatta neden Altaylı veya Sibiryalı ile aynı millet olmuyorum? (1992b, s. 156). 
Atsız, 30 Nisan 1973 tarihinde Ötüken dergisinde yayımlanan "Turanclık" adlı makalesinde şunları belirtmektedir:

Daha eski tarihimizde Babur'un 10.000 kişiyle Hindistan'a dalması, Yavuz'un 30.000 kişiyle çölü geçerek Mısır'a girmesi birer macera değil miydi? Evet, Napoleon ve Hitler'in Moskova seferleri de macera idi ama onlar başarısızlıkla bitti diye berikilerin değeri azalır mı? Yahudilerin artık Arap vatanı olmuş topraklarda Israil devletini kurması şaşırtıcı bir macera değil midir? (1992b, s. 11).

Ötüken dergisinde 1975 yılında yayınlanan "Bir Ansiklopedinin Yanlışları” isimli çalışmasında Atsız, Yahudilerin ülkü anlayışı ve Turancılık karşılaştırmasını şu şekilde yapmaktadır:

Büyük bir enerji kaynağı olan yüz milyonluk Türk milletinin birleşmesinde imkânsızlık görenler, iki bin yıllık tutsaklıktan sonra Yahudilerin kurduğu İsrail devletini görmemezlikten geliyorlardı. Daha kötüsü Turancılığı, Türkiye için macera, tehlike gibi görerek Turancıları Türkiye'nin mahvına sebep olacak insanlar diye tarif ediyorlardı (1992b, s: 19).

Atsız, 17 Kasım 1950 yılında Orkun dergisinin 7. sayısında yayınlanan "Ülküler Taarruzidir" isimli makalesinde milli ülkü kavramı üzerinden Yahudileri şu şekilde değerlendirmektedir:

İstiklâl uğrundaki savaşın en tipik örneğini Yahudiler vermiştir: Esâretleri yirmi asrı geçen, dünyanın her tarafına dağılarak bir anayurtları kalmayan ve dillerini de kaybeden Yahudiler, istiklâl sevkitabiisinin tesirinde olarak yaptıkları uzun ve yıpratıcı mücadeleden sonra millî ülkünün ilk merhalesine erdiler. Yanında müttefikleri olduğu halde Yahudilere yenilen Mısır ise Ingiltere'den Sudanı ve Trablus'la Bingazi'yi istiyor. Bütün nüfusu 400 bin kişi bile olmayan Ürdün beyliği Suriye ve Filistin'in hepsini istiyordu. Bu kadarını elde edemedi ama Yahudilerden arta kalan Filistin parçasını eklemesini becerebildi. Habeşistan, Eritre'yi istemektedir. Yahudiler ise milli birlik için Irak ve Yemendeki yüz bine yakın Yahudi'yi uçaklarla Israil'e taşıdılar (1992b, s. 30-31).

Ötüken dergisinin 26 Temmuz 1972 yılında yayınlanan 74. Sayısında bulunan "Milli Siyaset” adlı makalesinde Atsız, Arap-issrail savaşı hakkında şunları ifade etmektedir:

Yüzyıllar boyunca tutsaklık hayatı yaşadıkları için cesaretten nasibi kalmamış, geri ve bu bakımdan iptidaî Araplar'ı bugün hatırı sayılır bir kuvvet haline getiren şey Filistin dâvâsıdaki tutumları ve Yahudi düşmanlığıdır. Araplar İsrail'le üç defa çarpışıp yenildiler. Hele son yenilişleri pek yüz kızartıcı oldu. Buna rağmen inançları sarsılmadığı için yarın, büyük hamleler yapabilecek kudreti kendilerinde buluyorlar ve hazırlanıyorlar. İsrail de aynı durumdadır, iki bin yıllık tarihî haklara dayanarak yüzde yüz Arapların oturduğu toprakları işgal edip geri vermemekte direniyor. Oraları da devletine ekleyip yarın için on milyonluk bir İsrail devleti kurmak gayreti ve ülküsü içindeler. Bir batı Avrupa devleti niteliğinde olan İsrail'in on milyon nüfusa sahip olması Arap dünyasına karşı kendisini savunacak esaslı bir gücü elde etmesi ve geleceğini 


\section{Yusuf Ziya BÖLÜKBAŞI}

teminat altına alması demektir Türkiye, Atatürk'ün ölümünden beri pasif bir devlet siyaseti gütmektedir (1992d, s. 54).

"Kızılelma" isimli makalesinde Yahudilerin ülkü anlayışı ve bu çerçevede uyguladıkları politikalar hakkında şunları dile getirmiş̧i:

Yahudiler de, ülkü sahibi olmanın ikinci bir ibret verici örneğidir. Korkaklı̆ı̆ atasözü haline gelen bu millet, bugün, bir milli ülkünün ardında, herhangi bir millet kadar cesaretle çarpışıyor. Milli kahramanlar yetiştiriyor ve bu millî kahramanlar, idama mahkûm edildikleri ve bağışlanma dileğinde bulunurlarsa ölümden kurtulacakları halde, ingiltere'den af dilemeyerek milletlerine şeref vermek suretiyle ölüyorlar. Bu millî ülkü sayesinde, Filistin'deki yarım milyon Yahudi, yalnız Araplarla değil, koca ingiltere ile savaşı göze alıyor, Amerika'ya meydan okuyor. Millî ülküye yapısmak sayesinde Yahudiler o kadar kuvvetlenmişlerdir ki, bugün ingiltere imparatorluğu onlara karşı bir şey yapamıyor. Tebaasından bir tek kişinin hapse atılmasını savaş sebebi sayan ingiltere, bugün, Ingiliz askerlerinin öldürülmesine, Ingiliz subaylarının kaçırılıp dayak atılarak horlanmasına, masum ingiliz çavuşlarının Yahudiler tarafından canice asılmasına ses çıkaramıyor. Bütün bunların en önemli sebebi Arapların ve Yahudilerin olağan üstü kuvvetli olmasıdır. Bu kuvvet maddî değil, manevîdir. Yani ülkü kuvvetidir. Kızılelma ülküsüne "tehlikeli maceracılık" diyenler, bugünkü Araplar ile Yahudilere bakıp düşünmelidirler. Hele Yahudiler 2000 yı önce kaybettikleri vatanlarını yeniden ele geçirmek ve yalnı kitaplarda kalmış olan ibranî dilini diriltip bir konuşma dili haline getirmek uğrundaki çalışmaları ile dünyaya örnek olmuşlardır (1992c, s. 93).

Arap-İsrail Savaşı, İsrail'in bölgesel hegemonyası ve oluşturduğu tehdit hakkında, "Arapları Kurtarmak İçin Teklif” isimli makalesinde Atsız şunları belirtmektedir:

Biz şimdiye kadar dünyada 15 milyon kadar Yahudi var sanıyorduk. Moşe Dayan geçenlerdeki bir demecinde 70 milyon Yahudi'den bahsetti. Bu bir ajans haberi yanlışı veya Moşe Dayan'ın bir blöfü değilse cidden düşündürücü ve ürkütücü bir haberdir... 10 milyon nüfus, altı günlük savaştan önceki sınırlar içinde harmanlayacağından, Nâsır'ın yanlış tutumundan faydalanarak çevrelerindeki Arap devletlerine karşı giriştikleri yıldırım savaşıyla büyük bir toprak parçasını ve Kudüs şehrinin tamamını ele geçirdiler. Ne Arapların protestosu, ne Birleşmiş Milletlerin ihtarı, ne Amerika'nın tavsiyesi, ne de Rusya'nın tehdidi Yahudileri geri çeviremedi. Milî̀ plânlarını başarıyla uygulamakta devam ettiler. Aldıkları çölleri şenlendirmeye, Yahudi göçmenleri getirmeye ve yuttuklarını sindirmeye başladılar. Şimdiye kadar arabulmak için yapılan teklifler iki tarafa da taviz vermeyi tavsiye eden bir nitelikte olduğundan taviz asla kabullenmeyen taraflarca reddolundu. Araplar, Israil'i tanımamakta haklı oldukları gibi İsrail de zaptettiği topraklan vermemekte haklıdır. Bu, ta- 
rih boyunca süregelmiş uluslararası bir kanundur. İsrail yaşamaya muhtaç ve mecburdur. Araplar'ın hazırlıklarına, kalabalık nüfuslarına, teknik ve iktisadî ilerlemelerine bakarak günün birinde Araplar'ı yenemeyeceğini hesaplıyor. Kendisini yok olmaktan kurtarmak için de çareyi sınırlarını stratejik şekilde düzeltmek ve 10 milyon kişiyi barındıracak kadar genişletmekte buluyor.... İsrail bugün iki milyonluk nüfusuna rağmen Orta-doğuda bir "Prusya"dır. İsrail'in Yahudileri Balat Yahudisi değildir. Almanya, Ingiltere, Amerika, Macaristan ve Polonya'dan gelmiş şuurlu Yahudilerin çoğunlukta olduğu bu ülke millî inanç, disiplin, iktisadî güç, ileri teknik ve savaşçılık ruhu ile çok güçlü bir devlettir. En kuvvetli taraflarından birisi de dinlerinin millî din olmasıdır. Bugün yeryüzünde birkaç bin Karayım Türkü dışındaki bütün Museviler Yahudi'dir. Araplar'ı tehdit ederek isterlerse Şam'a ve Kahire'ye girecekleri hakkındaki sözleri gayet doğrudur.... Şu halde Türkler'le Araplar'ın çıkarları bir noktadan sonra birleşmektedir. O halde bunu önlemenin tek çaresi, artık pek işe yaramadığı belli olan askerî ittifaklar değil, bölgedeki Arap devletlerinin Türkiye ile konfederasyon halinde birleşmesidir. Türkiye'nin başkanlığında, 20-25 yıl için kurulacak konfederasyona Suriye, Lübnan, Ürdün ve Mısır girecektir. Bu konfederasyon Arap devletlerinin bağımsızlığını kaldırmayacak. Hatta onların bazı ülkeler de kendi özel elçilerini yollamasına engel olmayacaktır. Fakat 20-25 yıllık konfederasyon süresince Ordu ve Hariciye tek elden idare olunacak ve şüphesiz ordular Türk Genelkurmayının yönetiminde bulunacaktır. Böyle bir konfederasyon Suriye'nin hükümet darbesi ve İsrail'in Arap ülkelerine saldırması tehlikesini önleyecek, Ortadoğu uzun süre barışı sağlayarak Üçüncü Cihan Savaşının bu bölgeden çıkmasına engel olacak ve 20-25 yıl sonra, Arap ülkeleri kendi başlarına İsrail'e karşı koyacak duruma geçince yürürlükten kalkacaktır. Bizim teklifimiz Yahudiler'e Kudüs'ü ve Sînâ'yı bırak demekten daha pratiktir. Fakat Suriye, Lübnan ve Ürdün bu teklifi kabul etseler bile kendisini dev aynasında gören Nasır'ın kabul etmeyeceği muhakkaktır. Megalomanisi mânidir. $O$, kendi bileceği iş. Fakat Yahudi ordusu girdiği zaman kendine yardım edecek kimseyi bulamayacaktır (1992c, s. 215-217).

Atsız’ın, Yahudiler ve Yahudiliğe içkin kimlik ve ideolojilere karşı olan antisemitist tavırlarının bilinmesine karşılık, bazı yazılarında Yahudilerin İsrail'i kurmasını ve bölgede güçlü bir aktör olmasını, milli ülkü ekseninde takdir etmektedir. Ona göre Yahudiler, dünyanın dört bir tarafına dağıımış bulunan, aralarında, vatan, dil, ırk ve yaşayış biçimi itibariyle hiçbir ortak yan bulunmamasına karşın milli dinleri ve ülküleri sayesinde iki bin yıl sonra tekrar dirilen bir millettir. Özellikle iki bin yıldır milli ülkülerini bırakmamaları, vatanlarına geri dönmeleri ve İbrani dilini diriltmeleri Atsı tarafından takdire şayan bulunmaktadır. Her ne kadar hala onları "korkak" bir halk olarak telakki etse de, Atsız, Yahudilerin Filistin'i kolonize etmelerini, sırasıyla İngiltere ve Arap dünyasına karşı cesurca savaşmalarını, ABD ve SSCB gibi küresel güçlerin telkinleri ve uyarılarına kulak asmamalarının temel nedenini milli ülküye duydukları bağılıı olarak görmektedir. Atsız, kendi Türkçü-Turancı görüşlerini de İsrail örneği üzerinden yeniden üretmektedir. Özellikle resmi ideolojinin dış Türklere karşı ilgisiz tavrı ve kimliğin teritoryal tanımı Atsı tarafından eleştirilmekte; dünyanın farklı noktalarından 
Yusuf Ziya BÖLÜKBAŞI

gelen ve aralarında hiçbir bağ bulunmayan Yahudilerin tek bir millet olduğu kabul edilirken, neden bizim Genceli ya da Tebrizli birisiyle aynı milletin üyesi olduğumuzun kabul edilmediğini sorarak bu tarz yaklaşımlara itiraz etmektedir. Nasıl ki İsrail, yüzbinlerce Yahudi'yi Mısır ve Yemen'den uçaklarla getirdiyse, Türkiye de soydaşlarına aynı şekilde yaklaşması gerektiği, Atsız'ın altını çizdiği hususların başında gelmektedir. Ayrıca, "Turancılık" ya da "Kızılelma" olarak isimlendirdiği Türk ülküsüne yönelik "maceraclık" eleştirilerini reddeden Atsız, burada da Yahudi örneğinden hareketle, İsrail'in kuruluşunun, yarım milyonluk Yahudi toplumunun kendisinden kat be kat fazla olan Araplara karşı elde ettiği zaferlere bakılmasını tavsiye etmektedir. Atsız'a göre bunlar maceracilıktan ziyade milli ülkünün getirmiş olduğu manevi bir güçtür. Bu konuda Atsız, bazı tarihsel analojilere başvurarak, her ne kadar Napolyon ve Hitler'in Moskova seferleri başarısız olduysa da, Yavuz'un Mısır seferi, Babür'ün Hindistan seferi ya da Yahudilerin Arap topraklarında devlet kurmalarını da başarılı bir maceracılık örneği olarak sunmaktadır. Nitekim Atsız, Turancılığı hayal ve maceraperest olarak görenlerin İsrail örneğine bakmasını tavsiye ederek, bunun bir hayal olmadığını göstermek istemektedir. Atsız, Filistin Mandasının son dönemleri ve İsrail kurulduktan sonra yaşanan Arap-Yahudi savaşları hakkındaki düşüncelerini çeşitli yazılarında ifade etmiştir. Arapların İsrail karşısında küçük düşürücü yenilgiler alması, İsrail'in aslında Avrupa ve Amerika'dan gelen yetenekli, disiplinli, teknik ve iktisadi açıdan ilerlemiş bir Batı Avrupa ülkesi hüviyetinde olmasının üzerinde durmaktadır. Ancak Atsız, İsrail'i tehdit olarak görmeye devam etmektedir. Dünya üzerinde asıl Yahudi sayısının 70 milyon olmasını ürkütücü bulan Atsız'a göre İsrail tehlikesi karşısında Araplar ve Türklerin çıkarları kesişmektedir. Arapların İsrail tehlikesini karşı tek başına karşı koyacak gücü olmadığını belirten Atsız, Lübnan, Suriye, Mısır ve Ürdün'ün Türkiye ile geçici -20 ya da 25 yıllık- bir konfederasyon çatısı altında bir araya gelmelerini, Hariciye ve Ordunun Türk idaresi altında bulunmasını ve İsrail tehlikesi ortadan kalkınca bu birliğin dağılmasını önermektedir. Ancak Nasır gibi liderlerin buna karşı çıkacağını düşünen Atsız, bu teklifin kabul edilmemesi durumunda artık Arapların Türklerden yardım talep etmemesi gerektiğini dile getirmektedir.

\section{Sonuç}

Atsı'ın eserlerinde Yahudiler ve Yahudiliğe içkin olarak görülen kimlik ve ideolojiler (Komünizm, Siyonizm, Masonluk ve Sabetayistler-Dönmeler) bir öteki olarak kategorileştirilmekte ve modern antisemitizme uygun bir dil kullanılmaktadır. Çalışmanın ana sorunsalı olan Atsız'ın antisemitist yaklaşımındaki temel esas nedir? sorusunun cevabı ise antisemitizmin dini karakterinden ziyade ideolojik-ırki niteliklerinin belirgin olduğudur. Ortaçağ Avrupası'nda başlayıp 19. Yüzyıla kadar geçen süreçte antisemitizmin karakteri din temelliydi. Ancak moderniteyle birlikte ideolojilerin ortaya çıkışı, ulus-devletlerin kuruluşu ve milliyetçiliğin yükselmesiyle beraber Yahudi karşıtlığının da biçimi değişmiş, din yerini ırka bırakmıştı ve daha önce de belirtildiği üzere Klier'e göre antisemitizm Batılı entelektüel geleneğin ürünüydü. Atsız'ın yazılarında da bu geleneğin izleri görünmektedir. Her ne kadar Atsız, antisemitizmin klasik döneminde olduğu gibi Yahudilere ilişkin çeşitli sıfatlar kullansa da -korkak, yalancı, dolandırıcı, sinsi, sahtekâr, hain, kötü vs-, değerlendirmelerinin temelinde ırki yaklaşımlar bulunmaktadır. Bu ırki yaklaşımların merkezinde Yahudilerin Türk ola- 
mayacakları, Türkleşmemesi gerektikleri ve bunun Türkçüler tarafından arzulanmayacak bir durum olması bulunmaktadır. Bu minvalde en çok üzerinde durduğu konu Sabetayistler, ya da sıklıkla kullandığı şekliyle "Selanikli”-“Dönmeler” diye isimlendirdiği gruptur. Bunların Türk olmadıkları ve Türk gibi gözükerek aslında kendi kimliklerini korumaya çalıştıkları ve Türkiye aleyhine faaliyetlerde bulundukları meselesi, Atsız'ın yazılarında en çok karşılaşılan olgudur. Ona göre Sabetayistler Türkçülüğe düşman olup, Türkiye aleyhine sürekli çalışmaktadırlar. Bu yüzden polemik yazılarında bir kişiyi ötekileştirirken onun dönme-Selanikli-Sabetayist kimliğine sürekli atıf yapmaktadır. Bunun dışında Masonluk, Siyonizm ve Yahudiliğe ilişkin diğer düşünceleri bakımından küresel antisemitizme benzer fikirleri dile getirmektedir. Burada bir parantez de Komünizme açmak gerekir. Atsı'a göre komünizm, Yahudi Marks tarafından icat edilen ve Yahudice düşüncenin ürünü olan bir ideolojidir. Atsız eleştirdiği sol düşünce ve kişileri, hem Yahudi-Dönme, hem de komünist diye ifade etmek suretiyle iki kimliğin de ötekileştirilmesini sağlamaktadır. Böylece Atsız’ın bu tarz söylemleri, Türkçülüğü, siyasetin sağ yelpazesine yerleşmesine ve sağ siyasetin Yahudi karşıtlığına hizmet etmesini sağlamaktadır. Aslında komünizm ve Yahudi kimliğinin bir araya gelmesi yine modern antisemitizmin ürünüdür. Bununla birlikte, tefeci, küresel sermaye elinde bulundurma ve Masonluk gibi gizli bir yapıyla dünyayı ele geçirmeye çalışma söylemleri de Atsı'ın Yahudilere ilişkin söylemlerinde görülmektedir. Benzer şekilde bu söylemlerde modern antisemitizmin ürünüdür. Yani modern antisemitizmdeki, hem Marksist ideolojinin, hem de kapitalizmin yürütücüleri olan Yahudi kavramı, Atsız'ın eserlerine de yansımış, bu durum, Türkçülüğün her iki akım karşısında konumlanmasında etkili olmuştur.

Sonuç olarak, Türkçülüğün en güçlü kalemlerinden biri olan Atsız’ın yazılarında antisemitizm, ideolojik-ırki açıdan işlendiği görülmektedir. Yahudi olgusu ve ona ilişkin kimlik ve ideolojiler Atsız eserlerinde bir öteki olarak konumlandırımaktadır. Antisemitist yazıları ve soy temelli bir milliyetçilik anlayışına sahip olması nedeniyle Atsız’ın Nazi ideolojisinden etkilendiğine ilişkin bir düşünce bulunmaktadır. Ancak Atsız'ın Nazi rejiminden etkilenerek antisemitist düşüncelerini dile getirdiğini söylemek yanlış olur, zira Atsız’ın “sadece Yahudilere karşı olan Alman ırkçılığıyla, dünyadaki bütün milletlere karşı kendini koruma düşüncesi olan Türk ırkçılığı arasında bağlantı yoktur” (1992d: s. 14) sözü bunun en önemli kanıtıdır. Bunun yanında, eğer Atsız Nazi rejiminden etkilenmiş olsaydı, İkinci Cihan Harbinden sonra bu konuda yazmayı bırakması gerekirdi, oysa vefat ettiği yıla kadar Yahudilerle ilgili düşüncelerini ifade eden birçok makaleyi -metin içinde de görüldüğü üzere- kaleme aldı. Yine de Atsız'ın Türkçülük anlayışı salt Yahudi karşıtlığı temelinde anlaşılmaması gerekir. Doğu Avrupa milliyetçiliklerinin ortak yönünün antisemitizm olmasına karşılık (Lieberman, 2016, s. 71) Türk milliyetçiliğinin biçimlenmesinde farklı saikler bulunmaktadır, sadece Atsız’ın Türkçülük tasavvurunda Yahudiler, Türk olmayan bütün kimlikler gibi bir öteki olarak kodlanmaktadır. Atsız'ın farkı bunu modern antisemitizme içkin bir dille ifade etmesi ve bu konuyu eserlerinde sıklıkla işlemesidir. Bütün bunlara karşılık Atsız, Yahudileri takdir etmeyi de ihmal etmemektedir. Milli ülkü çerçevesinde hareket eden Yahudiler, iki bin yıl sonra anavatanlarına dönüp dillerini diriltmişler ve güçlü bir devlet kurarak bütün Arap dünyasına kafa tutmuşlardır. Atsız, Yahudilerin İsrail'i kurmalarından hareketle Türkçü-Turancı politikaları meşrulaştırmayı ihmal etmemekte ve Turancılığa maceraperestlik diyenlere İsrail örneğini göstermektedir. Yine de Atsız için İsrail ve Yahudiler büyük bir 
Yusuf Ziya BÖLÜKBAŞI

tehlike arz etmektedir. Bu konuda, genellikle yazılarında "kalleş" olarak nitelendirdiği Araplara bile yardım edilmesini ve Türkiye önderliğinde bir konfederasyon kurulması suretiyle İsrail revizyonizminin sonlandırılmasına ilişkin önerisi de dikkat çekici bir husustur.

\section{Kaynaklar}

Akçam, T. (2009). Türk Ulusal Kimliği Üzerine Bazı Tezler. Ed. Tanıl Bora ve Murat Gültekingil. Modern Türkiye'de Siyasi Düşünce: Milliyetçilik Cilt 4. İstanbul: İletişim Yayınevi.

Aktar, A. (2004). Varlık Vergisi ve "Türkleştirme" Politikaları. İstanbul: iletişim Yayınevi.

Atsız, H. N. (2015). Çanakkale'ye Yürüyüş/Türkçülüğe Karşı Haçıı Seferleri. İstanbul: İrfan Yayıncılık.

Atsız, H. N. (1992a). Makaleler I. İstanbul: Baysan Yayıncılık.

Atsız, H. N. (1992b). Makaleler III. İstanbul: Baysan Yayınclık.

Atsız, H. N. (1992c). Makaleler IV. İstanbul: Baysan Yayınclık.

Atsız, H. N. (1992d). Türk Ülküsü. İstanbul: Baysan Yayıncılık.

Aydemir, Ş. S. (2016). Suyu Arayan Adam. İstanbul: Remzi Kitabevi.

Aydın, S. (2009). Cumhuriyet'in İdeolojik Şekillenmesinde Antropolojinin Rolü Irkçı Paradigmanın Yükselişi ve Çöküşü. Ed. Tanıl Bora ve Murat Gültekingil. Modern Türkiye'de Siyasi Düşünce: Kemalizm Cilt 2. İstanbul: Illetişim Yayınevi.

Bali, R. N. (2009). Tekin Alp. Ed. Tanıl Bora ve Murat Gültekingil. Modern Türkiye'de Siyasi Düşünce: Milliyetçilik Cilt 4. İstanbul: Illetişim Yayınevi.

Bali, R. N., Yumul, A., Benlisoy, F. (2009). Yahudi, Ermeni ve Rum Toplumlarında Milliyetçilik. Ed. Tanıl Bora ve Murat Gültekingil. Modern Türkiye'de Siyasi Düşünce: Milliyetçilik Cilt 4. İstanbul: iletişim Yayınevi.

Berber, Ş. G. (2012). Osmanlı'dan Cumhuriyete Geçişte Yahudilerin Türkiye Cumhuriyeti Devletine Uyum Süreci: Moiz Kohen Örneği. Turkish Studies- International Periodical For the Languages, Literature and History of Turkish or Turkic 7. N4. 1779-1800. Erişim Adresi: http://www.acarindex.com/dosyalar/makale/acarindex-1423933429.pdf.

Besalel, Y. (2004). Osmanlı ve Türk Yahudileri. İstanbul: Gözlem Gazetecilik ve Basın Yayıncılık AŞ.

Bora, T. (2009). "Ekalliyet Yılanları..." Türk Milliyetçiliği ve Azınlıklar. Ed. Tanıl Bora ve Murat Gültekingil. Modern Türkiye'de Siyasi Düşünce: Milliyetçilik Cilt 4. İstanbul: İletişim Yayınevi.

Bora, T. (2017). Cereyanlar: Türkiye'de Siyasal Ideolojiler. İstanbul: İletişim Yayınevi. 
Bölükbaşı, Y. Z. (2018). Türkçü-Turancı Milliyetçiliğin Düşünsel Temelleri Üzerine Bir İnceleme. Akademik Hassasiyetler. C5/S10. 45-60. Erişim Adresi: https://dergipark.org.tr/tr/download/article-file/613342.

Cleveland, W. L. (2008). Modern Ortadoğu Tarihi. Çev. Mehmet Harmancı. İstanbul: Agora Kitaplığı.

Çağaptay, S. (2009). Otuzlarda Türk Milliyetçiliğinde Irk, Dil ve Etnisite. Ed. Tanıl Bora ve Murat Gültekingil. Modern Türkiye'de Siyasi Düşünce: Milliyetçilik Cilt 4. İstanbul: İletişim Yayınevi.

Çelik, H., Ekşi, H. (2013). Söylem Analizi. Marmara Üniversitesi Eğitim Bilimleri Fakültesi Dergisi. 27(27). 99-117. Erişim Adresi: https://dergipark.org.tr/tr/pub/maruaebd/issue/365/2517.

Deliorman, A. (2014). Atsız. Ankara: Berikan Yayınevi.

Dündar, F. (2009). Milli Ezber: Saf Türk-Karışık Öteki. Türk Milliyetçiliği İdeolojisinin Doğuşu ve Özellikleri. Ed. Tanıl Bora ve Murat Gültekingil. Modern Türkiye'de Siyasi Düşünce: Milliyetçilik Cilt 4. İstanbul: Iletişim Yayınevi.

Düzgün, M. (2000). Cumhuriyetin İlanından İsrail'in Kuruluşuna Kadar Türkiye'deki Yahudiler. DEÜ Atatürk Ilkeleri ve Inkilap Tarihi Enstitüsü Çağdaş Türkiye Araştırmaları Dergisi, C3/S9-10, 6583. Erişim Adresi: https://acikerisim.deu.edu.tr/xmlui/bitstream/handle/20.500.12397/4873/mucahit duzgun. pdf?sequence=1\&isAllowed=y.

Edel, P. (2008). Siyonizm'in Tarihi: Yıldızın Gölgesi. Çev. Burak Sengir. İstanbul: Ceylan Yayınları.

Ercilasun, A. B. (2018). Atsız: Türkçülüğün Mistik Önderi. Ankara: Panama Yayınclık.

Ertekin, O. (2009). Cumhuriyet Döneminde Türkçülüğün Çatallanan Yolları. Ed. Tanıl Bora ve Murat Gültekingil. Modern Türkiye'de Siyasi Düşünce: Milliyetçilik Cilt 4. İstanbul: Illetişim Yayınevi.

Gans, C. (2008). A Just Zionism: On The Moralty Of The Jewish State. Oxford: Oxford University Press.

Herzl, T. (2017). Yahudi Devleti. Çev. Hakan Başak. İstanbul: Sümer Kitabevi.

Klier, J. (2001). Antisemitism. Ed. Athanea S. Leoussi, Encyclopaedia of Nationalism, New Brunswick and London: Transaction Publishers,

Kösoğlu, N. (2009). Türk Milliyetçiliği İdeolojisinin Doğuşu ve Özellikleri. Ed. Tanıl Bora ve Murat Gültekingil. Modern Türkiye'de Siyasi Düşünce: Milliyetçilik Cilt 4. İstanbul: İletişim Yayınevi.

Lewis, B. (2018). Semitizm ve Antisemitizm Çatışma ve Önyargıya Dair. Çev. Hür Güldü. Ankara: Akılçelen Kitapları.

Lieberman, B. (2016). Korkunç Kader: Modern Avrupa'nın Oluşumunda Etnik Temizlik. Çev. Damla Tanla Kurt, Ankara: Heretik Yayınevi. 


\section{Yusuf Ziya BÖLÜKBAŞI}

Motyl, A. J. (Ed) (2001). Encyclopedia of Nationalism: Leaders, Movements and Concepts II. London: Academic Press.

Sertkaya, O. F., (2014). Hüseyin Nihal Atsız. İstanbul: Ötüken Yayınevi.

Yalçıner, G. D. (2011). Eleştirel Söylem Analizi Çerçevesinde Avrupa Birliği'nde Kültürlerarası Diyalog. Hacettepe Üniversitesi Sosyal Bilimler Enstitüsü. Yayımlanmamış Doktora Tezi. Ankara.

Yeğen, M. (2006). Mustakbel Türk'ten Sözde Vatandaşa Cumhuriyet ve Kürtler. İstanbul: Iletişim Yayınevi. 